\title{
THE RATIONAL EXUBERANCE OF Structuring Venture Capital Startups
}

\author{
Victor Fleischer \\ Acting Professor of Law \\ UCLA School of Law \\ fleischer@law.ucla.edu
}

Draft of $8 / 7 / 03$

This Article takes the bursting of the dot com bubble as an opportunity to reevaluate the tax structure of venture capital startups. By organizing startups as corporations rather than as partnerships, investors and entrepreneurs seem to leave money on the table by failing to fully use tax losses-e specially since the vast majority of startups fail. Conventional wisdom attributes the lack of attention paid to losses to a "gambler's mentality" or optimism bias. I argue here that the use of the corporate form is, in fact, rational, or at least that there is a method to the madness.

I make four main points. First, the tax losses are not as valuable as they might seem; tax rules prohibit many investors from capturing the full benefit of the losses. Second, the VC professionals who structure the deals do not personally share in the losses, so they have little reason to care about the tax effects of the losses. Third, gains are taxed more favorably if the startup is organized as a corporation from the outset, and again, this favorable treatment of gains is especially attractive to the VC professionals further evidence that agency costs may be playing a role here. Fourth, corporations are less complex than partnerships: organizing as a corporation minimizes legal costs and simplifies employee compensation and exit strategy. 


\title{
The Rational Exuberance OF Structuring Venture Capital Startups
}

\author{
Victor Fleischer ${ }^{1}$
}

The venture capital market imploded in 2001. It was the worst year for VC investors in recent history - indeed, only the second year in the last thirty with four quarters of negative returns. ${ }^{2}$ With losses, not gains, now on everyone's mind, this Article takes the bursting of the dot com bubble as an opportunity to reevaluate the tax structure of venture capital startups. Prior commentators have pointed out that venture capital startups are structured in a tax-inefficient manner, particularly regarding losses. ${ }^{3}$ A typical startup is organized as a corporation under state law, which means that it is treated as a separate entity from its owners for tax purposes. ${ }^{4}$ If a startup were instead organized as a partnership or limited liability company (LLC), it could elect "passthrough" treatment for tax purposes. ${ }^{5}$ The gains or (more likely) the losses of the new business would flow through to the investors, with each investor recognizing its share of taxable income or loss. ${ }^{6}$ A startup's tax losses are potentially very valuable to certain investors. ${ }^{7}$ Because a startup is typically organized as a corporation, however, its

\footnotetext{
${ }^{1}$ Acting Professor of Law, UCLA Law School. Comments are welcomed and should be directed to the author at (310) 825-6690 or by email at fleischer@law.ucla.edu. I am most grateful for the helpful comments on this paper from my generous friends and colleagues in practice and in academia, including Anne Alstott, Joseph Bankman, Matt Bodie, Andy Berg, Mel Eisenberg, Bill Gentry, Bill Gifford, Ron Gilson, Vic Goldberg, Jeffrey Gordon, Steve Hall, Sang Ji, Calvin Johnson, Avery Katz, Stewart Karlinsky, Elliott Manning, Marty McMahon, David Schizer, Larry Zelenak, and for the comments and questions of participants at various job talks and workshops, including the Columbia Law School Blue Sky Series, the Tax Policy Colloquium at Penn, and the Mid-year Meeting of the American Taxation Association.

${ }^{2}$ See "Value of Investments in Venture Capital Continues to Decline," Wall St. J., Oct. 17, 2001, at C13. The average portfolio lost 28 percent of its value; the average early stage portfolio, 34 percent. See Robert Clow, "VC Returns Down in 2001," Financial Times, June 11, 2002, at P31.

${ }^{3}$ See Joseph Bankman, The Structure of Silicon Valley Start-Ups, 41 UCLA L. Rev. 1737, 1738 (1994) (hereinafter Bankman, Silicon Valley Startups).

${ }^{4}$ See $\S \S 11,7701$. Unless otherwise noted, all statutory citations herein are to the Internal Revenue Code.

${ }^{5}$ See Treas. Reg. § 301.7701-2,- 3 (check-the-box rules).

${ }^{6}$ See $\S \S 701,704$ (passthrough treatment of partnerships).

${ }^{7}$ See Bankman, Silicon Valley Startups, supra note 3, at 1738 ("The unfavorable tax treatment ... gives the newly-formed corporation an after-tax return on investment that is considerably less than that realized by the partnership or established company."). Professor Bankman focuses on Silicon Valley startups in particular rather than venture capital startups generally. I have not observed any relevant distinctions between the organizational choices of startups in New York, where I practiced, and Silicon Valley. For a
} 
tax losses get trapped at the entity level and can only be carried forward as a net operating loss (NOL), which is less valuable. ${ }^{8}$ Lawyers who advise venture capital professionals understand the tax effects of structuring a startup as a corporation. The corporate law differences between a limited liability company and a privately-held corporation are relatively minor. ${ }^{9}$ Why, then, do nearly all startups choose the seemingly less tax-efficient structure? Should post-bubble deal planners revise the standard deal structure to better account for losses?

Conventional wisdom attributes the choice of deal structure to a kind of irrational exuberance. People are foolishly biased towards thinking about gains, not losses. ${ }^{10}$ Entrepreneurs and venture capitalists, dreaming of gains, discount the value of tax losses generated by a startup. ${ }^{11}$ In an important 1994 Article, The Structure of Silicon Valley Start-Ups, Professor Joseph Bankman described these people as suffering from a "gambler's mentality" which leads them to overestimate their likelihood of success. ${ }^{12}$

discussion of regional differences and their impact on the venture capital industry, see AnnaLee Saxenian, REgional AdVANTAge: CUltuRE AND COMPETITION IN Silicon VALLEY AND Route 128 (1994).

${ }^{8}$ See Bankman, Silicon Valley Startups, supra note 3, at 1743-44.

${ }^{9}$ See discussion at infra text accompanying notes 128-136.

${ }^{10}$ The phrase "irrational exuberance" is borrowed, of course, from Federal Reserve Chairman Alan Greenspan's famous speech to the American Enterprise Institute on December 5, 1996. See http://www.federalreserve.gov/boarddocs/speeches/1996/19961205.htm (last visited August 30, 2002) ("But how do we know when irrational exuberance has unduly escalated asset values, which then become subject to unexpected and prolonged contractions as they have in Japan over the past decade?").

${ }^{11}$ Bankman noted a lack of interest in tax losses both among potential limited partner investors, see Bankman, Silicon Valley Startups, supra note 3, at 1759-63, and among the entrepreneurs and VCs, see id. at 1764-65. Bankman also emphasized the general lack of tax sophistication among VC professionals. See id. at 1747 (“... perhaps the most surprising aspect of [executives and venture capitalists] was the relative lack of awareness of or interest in the tax consequences of the organization structure they had chosen.").

${ }^{12}$ See Bankman, Silicon Valley Startups, supra note 3, at 1764-66 (explaining that "the most common explanation for the industry structure" is that "[a]ttention to tax benefits from early losses runs counter to the expansive mind-set of inventors and venture capitalists. 'By their very nature,' one lobbyist stated, 'the kinds of people going into these things are very optimistic people[.]"'). To be fair, Professor Bankman did not accept "gambler's mentality" as the primary explanation for the lack of attention to tax losses, but rather saw it as contributing to the collective action problem that makes tax losses (and, in his view, a more rational and efficient tax structure) a "hard sell." See id. In the years since Professor Bankman's article, other commentators have picked up the theme that the structuring decision is irrational. See Daniel S.

Goldberg, Choice of Entity for a Venture Capital Start-up: The Myth of Incorporation, 55 Tax Lawyer 923, 924 (2002) ("This article asserts that advisors who advise immediate incorporation are relying largely on myths that the corporation, rather than the LLC, is the more desirable entity for a start-up seeking venture capital funding."). 
Like blackjack players on their way to Las Vegas, they refuse to even think about losses, and they are hardly willing to plan the adventure with losses in mind. ${ }^{13}$

This Article argues that even in the post-bubble era the exuberance of venture capital deal planners is rational, or, at least, that there is a method to the madness. There is surely some truth in the observation that startups are organized in a tax-inefficient manner: partnerships are, on paper, more tax-efficient than corporations. ${ }^{14}$ But various "frictions" - non-tax business costs such as transaction costs, information problems, reputational concerns, and adverse accounting treatment - currently prevent deal planners from using the theoretically tax-favorable form. ${ }^{15}$ If these frictions wear down over time, we may well see more startups organized as partnerships. But for now I think it is a mistake to conclude that startups are organized irrationally, or to accept the conventional wisdom that a casino mentality or some other cognitive bias explains the behavior of deal planners.

I make four main points. First, the tax losses are not as valuable as they might seem; tax rules prohibit many investors from capturing the full benefit of the losses. Second, the VC professionals who structure the deals do not personally share in the losses, so they have little reason to care about the tax effects of the losses. Third, gains are taxed more favorably if the startup is organized as a corporation from the outset, and again, this favorable treatment of gains is especially attractive to the VC professionals -

\footnotetext{
${ }^{13}$ See SwINGERS (screenplay by Jon Favreau, 1997) (Mike: "Do you think we'll get there by midnight?" Trent: "Baby, we'll be up five hunny [hundred] by midnight.")

${ }^{14}$ There is a rich literature discussing the "corporate integration" question, with most commentators concluding that it would be wise to tax corporations and partnerships in a similar manner. See generally American Law Institute, Federal Income Tax Project-Taxation of Private Business Enterprises (George K. Yin \& David J. Shakow reps.) (1999); George K. Yin, The Future Taxation of Private Business Firms, 4 Florida Tax Rev. 141, 150-154 (1999) (advocating a two-track integrated system of conduit taxation); Alvin Warren, The Relation and Integration of Individual and Corporate Income Taxes, 94 Harv. L. Rev. 717, 736-38 (1981) (questioning fairness of double tax). Most articles discussing the tax efficiency of partnerships focus on gains rather than losses and the effect of the second level of tax imposed at the entity level. See, e.g., Susan Pace Hamill, The Limited Liability Company: A Catalyst for Exposing the Corporate Integration Question, 95 Mich. L. Rev. 393, 395 (1996) (explaining partnership advantage of one level of tax on gains). Professor Bankman's article is one of only a few articles, outside the context of discussing abusive tax shelters, to focus on the tax inefficiency caused by the corporate form's trapping of losses.

${ }^{15}$ For a discussion of the concept of frictions, see generally Myron S. Scholes \& Mark A. Wolfson et al., TAXES AND Business STRATEgY: A PlanNing APPROACH 107-18 (2d ed. 2002) (describing how frictions restrict tax arbitrage); David M. Schizer, Frictions as a Constraint on Tax Planning, 101 Colum. L. Rev. 1312, 1315-17 (2001) (explaining concept of using frictions such as high transaction costs, adverse financial accounting, or unappealing regulatory treatment to constrain abusive tax planning).
} 
further evidence that agency costs may be playing a role here. Fourth, corporations are less complex than partnerships: organizing as a corporation minimizes legal costs and simplifies employee compensation and exit strategy.

This Article makes two contributions to the existing academic literature. ${ }^{16}$ First, I present a solution to the puzzle of why startups are structured as corporations, showing how agency costs, transaction costs, and the practical application of some key tax rules impact the structuring decision in ways not considered by prior commentators. Second, this Article calls attention to the value of seeking out rational explanations before accepting irrational ones - especially when analyzing the behavior of sophisticated experts. In recent years, the legal academy has increasingly focused on cognitive biases and has drawn on the growing scholarship in the field of behavioral economics. ${ }^{17}$ Although Professor Bankman's article predates the recent cascade of behavioral law and economics papers, a significant portion of his explanation of venture capital organization correlates with the "optimism bias" concept found in the behavioral literature - the phenomenon that people tend to overestimate their abilities and likelihood of success. ${ }^{18}$

\footnotetext{
${ }^{16}$ The existing literature on this topic is quite thin. Other than Professor Bankman's article, most tax articles discussing the structuring of startups are written by practitioners, focus on narrow issues, and tend to accept the use of the corporate form for startups as a given. See Thomas A. Humphreys \& Nizam M. Siddiq, Tax Considerations for Venture Capital and Technology-Related Start-Ups, 477 PLI / Tax 747, 757 (2000) (briefly describing advantages of corporate form as including simplicity and protecting tax-exempt and foreign investors from flowthrough consequences); Armando Gomez, Selected Issues Relating to Domestic and Foreign Technology Start-Ups and Joint Ventures, 498 PLI / Tax 975, 987 (2001) (noting that public companies are taxed as C Corporations, that only corporations may be acquired in tax-free reorganizations under $\S 368$, and that only corporations may use incentive stock options under $\S 421)$; Ellen B. Corenswet, Formation and Financing of Internet Start-ups, 610 PLI / Pat 489 (2000) (explaining that VCs traditionally prefer C Corps, but that friends and family or angel investors might prefer LLCs). Other articles focus on corporate law rather than tax law. See also J. William Callison, Venture Capital and Corporate Governance: Evolving the Limited Liability Company to Finance the Entrepreneurial Business, 26 J. Corp. L. 97, 108 (2000) (focusing on non-tax issues and attributing preference for corporations to lack of role differentiation between owners and managers under default LLC statutes).

${ }^{17}$ See Cass R. Sunstein, Foreword: On Academic Fads and Fashions, 99 Mich. L. Rev. 1251, 1258 (2001) (describing "cascade" effect with respect to behavioral economics literature); Jon D. Hanson \& Douglas A. Kysar, Taking Behavioralism Seriously: The Problem of Market Manipulation, 74 N.Y.U. L. Rev. 630, 640-687 (surveying behavioral law and economics literature) (1999); Christine Jolls \& Cass R. Sunstein, A Behavioral Approach to Law and Economics, 50 Stan. L. Rev. 1471, 1476-80 (1998) (providing overview of behavioral law and economics approach).

${ }^{18}$ See Hanson \& Kysar, supra note 18, at 654-58 (surveying optimism bias literature); Jon D. Hanson \& Kyle D. Logue, The Costs of Cigarettes: The Economic Case for Ex Post Incentive-Based Regulation, 107 Yale L.J. 1163, 1186-88 (1998) (describing third-person effect bias, i.e., assumption that bad things happen to other people); Susan J. Stabile, The Behavior of Defined Contribution Plan Participants, 77 N.Y.U. L. Rev. 71, 91 (2002) (describing effect of optimistic bias on behavior of defined contribution plan participants); William Meadow \& Cass Sunstein, Statistics, Not Experts, 51 Duke L.J. 629, 639-640 (2001)
} 
While the psychological phenomenon of optimism bias may be part of the story here, this Article shows that there is much more to it. Sophisticated actors who are unaffected by optimism bias - or whose optimism was crushed by the recent bear market - would rationally make the same organizational choice as the stereotypical Silicon Valley VC afflicted with rose-tinted vision. The broader point is that cognitive biases, though sometimes enlightening, should be used as a last resort rather than as a primary or allpurpose explanation for seemingly irrational behavior. If identifying these biases keep us from rigorously testing rational explanations, we may sometimes miss the subtle yet important details that can help account for the behavior of sophisticated actors in a complex marketplace. ${ }^{19}$

This Article is divided into five short parts. Part I explores the tax benefits of the partnership structure. Part II describes various limits on taxpayers' ability to use those tax benefits. Part III considers agency costs and the advantages the corporate structure provides to entrepreneurs and VCs, especially with respect to the tax treatment of gains. Part IV compares the simplicity of the corporate structure with the relative complexity of the partnership structure. Part V concludes.

(discussing role of optimism bias in regulating doctor-patient relationship). A Westlaw search of law review articles reveals 71 separate articles referring to "optimistic bias" or "optimism bias," most of which appear in the last 3 years, and 65 of which postdate Professor Bankman's 1994 article (search conducted August 30, 2002 in Westlaw's JLR database).

${ }^{19}$ Details are especially important in considering the effects of tax rules, which are often easy for a layperson to misunderstand but nonetheless affect the behavior of well-advised parties, even if the parties themselves do not fully understand the rules and simply rely on the advice of counsel. 


\section{The PuZzLe}

Entrepreneurs are optimists. ${ }^{20}$ They believe that their ideas, like the children of Lake Wobegon, are all better than average. ${ }^{21}$ This cognitive bias leads to a heightened sense of confidence and control, blunting the perception of risk and masking the likelihood of failure. ${ }^{22}$ In a recent study, more than one-third of Silicon Valley engineers rated their performance among the top 5\% of all engineers, and nearly $90 \%$ placed their performance in the top 25\%. ${ }^{23}$ Given this cognitive bias, the gambler's mentality of Silicon Valley would appear to be a plausible explanation for why startups are organized as corporations. A behavioral law and economics approach would suggest that entrepreneurs and VCs are foolishly optimistic and should pay more attention to losses. ${ }^{24}$ As sober-minded and dispassionate lawyers, should we throw a wet blanket over this irrational exuberance? ? $^{25}$

\footnotetext{
${ }^{20}$ A story of irrational exuberance would be consistent with much of the existing literature on the mindset of entrepreneurs. See Donald C. Langevoort, Taking Myths Seriously: An Essay for Lawyers, 74 Chi-Kent L. Rev. 1569, 1584 ("“S]tart-up entrepreneurs are a well-studied breed, prone toward greater over-optimism and illusions of control than the general population.”); Lowell W. Busenitz \& Jay B. Barney, Differences Between Entrepreneurs and Managers in Large Organizations: Biases and Heuristics in Strategic DecisionMaking, 12 J. Bus. Venturing 9, 15 (1997); Leslie E. Palich \& D. Ray Bagby, Using Cognitive Theory to Explain Entrepreneurial Risk Taking, 10 J. Bus. Venturing 425 (1995); Po Bronson, The Nudist on the Late Shift and Other True Tales of Silicon Valley (1999); STARTUP.COM (2001) (describing the rise and fall of govWorks.com).

${ }^{21}$ Garrison Keillor famously ends his public radio show, A Prairie Home Companion, by saying goodbye from Lake Wobegon, where "the women are strong, the men are good-looking, and all the children are above average." See http://prairiehome.org (site last visited August 30, 2002)

${ }^{22}$ See Langevoort, supra note 20, at 1583 (explaining cognitive bias of entrepreneurs); Busenitz \& Barney, supra note 20 , at 15 .

${ }^{23}$ See Joseph Bankman \& Ronald J. Gilson, Why Start-ups, 51 Stan. L. Rev. 289, 291 n.3, citing Todd R. Zenger, Compensating for the Innovation: Do Small Firms Offer High-Powered Incentives that Lure Talent and Motivate Effort?, John M. Olin School of Business Working Paper No. 96-24, 1996.

${ }^{24}$ See generally Langevoort, Taking Myths Seriously, supra note 20, at 1585-87 (discussing lawyer's ethical duty in the face of entrepreneurial over-optimism); Mark C. Suchman \& Mia Cahill, The Hired Gun as Facilitator: Lawyers and the Suppression of Business Disputes in Silicon Valley, 21 Law \& Soc. Inquiry 679, 683 (1996) (describing Silicon Valley lawyers' role in mitigating deal uncertainties); Donald C. Langevoort, Angels on the Internet: The Elusive Promise of "Technological Disintermediation" for Unregistered Offerings of Securities, 2 J. Small \& Emerging Bus. L. 1, 15 (1998) (discussing role of intermediaries in dealing with entrepreneurial over-optimism); Manuel Utset, Innovation \& Governance (check cite). Compare D. Gordon Smith, Venture Capital Contracting in the Information Age, 2 J. Small \& Emerging Bus. L. 133, 155 (1998) (expressing skepticism about gambler's mentality as a significant explanation for entrepreneurial behavior); Lisa Bernstein, The Silicon Valley Lawyer as Transaction Costs Engineer?, 74 Or. L. Rev. (1995).

${ }^{25}$ For an example of the wet blanket approach, see Goldberg, supra note 12 (debunking the "myths" that lead to choosing the C Corp Structure).
} 
In fact, while it may be true that entrepreneurs and VCs are overly optimistic, it does not necessarily follow that this cognitive bias drives the choice of organizational form. Optimism in the venture capital industry can be a conversation-stopper, just as risk aversion can be improperly used as an intellectual crutch to explain institutional arrangements like hedging or insurance. ${ }^{26}$ If anything, recent data show a lack of correlation between optimism bias and deal structure: post-bubble investors have displayed signs of pessimism, not optimism, and yet deal structures largely remain the same. ${ }^{27}$ Optimism bias is an unsatisfying explanation, and the importance of the puzzle millions of dollars of tax losses left on the table, year after year - warrants a closer look. $^{28}$

\section{A. The Alternative Structures: C Corp and Passthrough}

Some numerical examples may help illustrate the importance of deal structure to the bottom line. To analyze the fiscal consequences of organizing as a corporation rather than as a partnership, I will use two hypothetical startups, GainCorp, which begins its life as a C Corporation ${ }^{29}$ (the C Corp Structure), and LossLLC, which begins its life as an

\footnotetext{
${ }^{26}$ See Victor P. Goldberg, Aversion to Risk Aversion in the New Institutional Economics, J. Inst. \& Theor. Econ. 1989.

${ }^{27}$ The number of VC funds raised in 2001 dropped by $51 \%$, and total capital commitments dropped by 62\%. See 2002 National Venture Capital Association Yearbook (Thomson Financial \& Venture Economics) at 10. See also Lou Whiteman, "VCs Pessimistic, Dismiss Terrorism," Daily Deal, Oct. 16, 2001, at pin ("The outlook for startups is so bleak that even venture capitalists are dissuading entrepreneurs from seeking venture funding, according to a new study.”)

${ }^{28}$ Professor Bankman did explore other possible explanations in his article, noting that he found it troubling to discover that sophisticated investors were consistently choosing a bad deal structure, and it would be unfair to characterize his Article as a simple adoption of the gambler's mentality view. But I think it is fair to say that Bankman tended to focus on irrational explanations rather than rational ones, and that most of his Article tends to come back, one way or another, to cognitive bias. See Bankman, Silicon Valley Startups, supra note 3, at 1747 (noting surprise at overall lack of tax awareness among executives and venture capitalists).
}

Perhaps more importantly, subsequent commentators have fully embraced the irrational exuberance explanation. See Goldberg, supra note 12, at 943 (“... stock options may be a means of attracting young high-tech but financially unsophisticated employees, ready to overvalue the options as compensation and therefore accept less cash compensation than the actual value of the options would warrant. Perhaps this represents a real value of incorporating in the era of irrational exuberance.")

${ }^{29}$ Most corporations are "C Corporations" because they are taxed under subchapter C of the tax Code, as distinguished from "S Corporations," which are taxed under subchapter S. Certain closely-held corporations may elect subshapter S treatment. Unless otherwise noted, references in this Article to corporate tax treatment refer to C Corporations, not S Corporations. S Corporations are not generally suitable for venture capital startups because of the restrictions on the types of shareholders permitted and 
$\operatorname{LLC}^{30}$ (the Passthrough Structure). Assume for now that each company is engaged in the same business, with the same caliber of talent and the same likelihood of success in the marketplace.

\section{THE C CORP STRUCTURE}

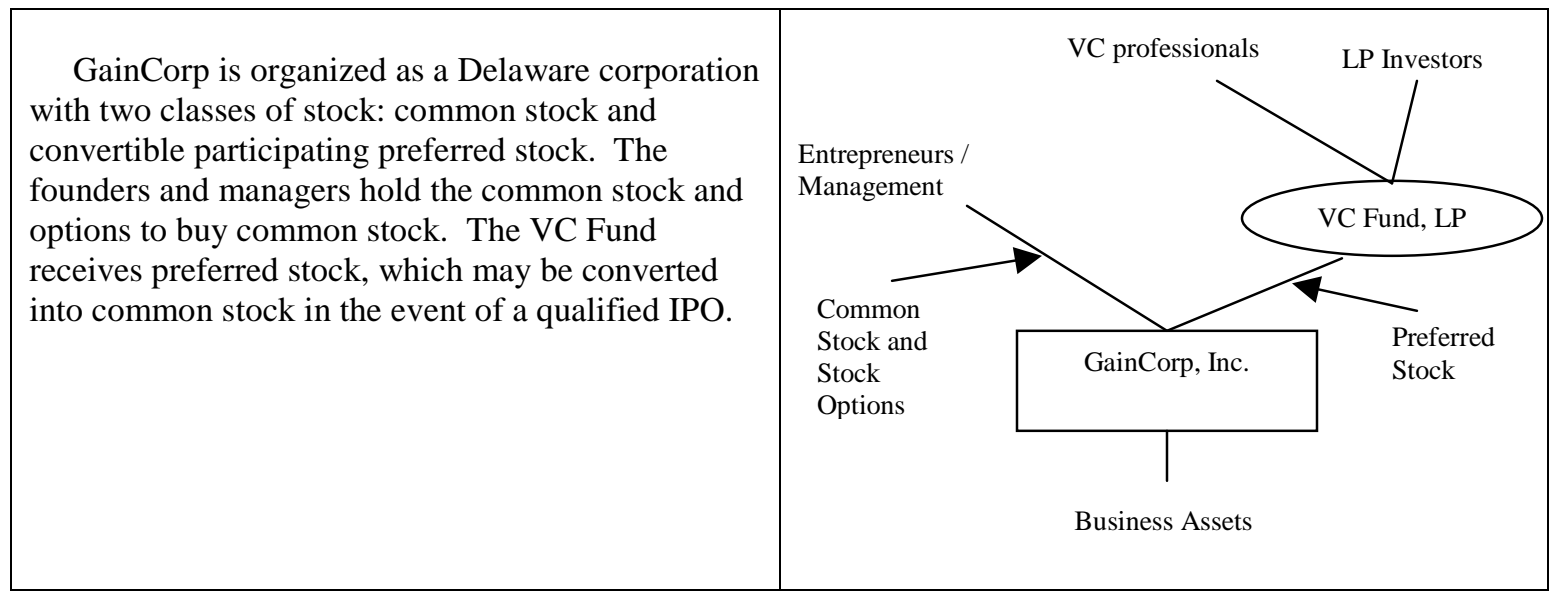

\section{THE PASSTHROUGH STRUCTURE}

LossLLC is organized as a Delaware limited liability company. The VC Fund receives $100 \%$ of the capital interests in the LLC. The founders and managers receive profits interests and partnership options.

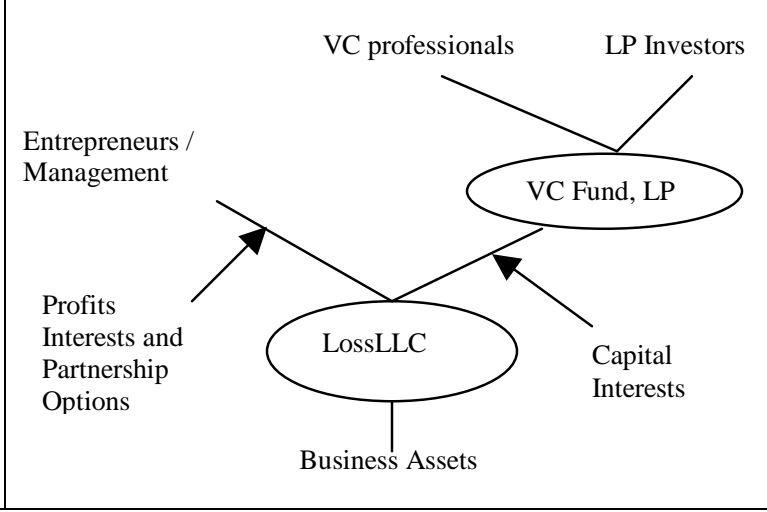

The economic deal struck among the parties is the same in both structures. ${ }^{31}$ The VC Fund, which itself is a partnership funded by limited partners (LP Investors, or LPs),

on the way the economics of the deal can be allocated. See $\S 1361(\mathrm{~b})(1)(\mathrm{B})$ (only individuals and certain estates and trusts permitted as S Corp shareholders); § 1361(b)(1)(D) (only one class of stock permitted).

${ }^{30}$ The reader should note that although LLCs and limited partnerships differ in terms of governance and corporate law, each is normally treated as a partnership for tax purposes (i.e., as a passthrough entity), and when I refer to partnership tax treatment, the reference should be read to include the tax treatment of LLCs as well as partnerships.

${ }^{31}$ The deal structures of venture capital investments tend to look very much alike. Although the economics of the investment vary greatly from deal to deal - valuations vary; sometimes VCs take a large stake in the 
invests in the startup. In exchange, the VC Fund receives both downside protection and upside potential. ${ }^{32}$ But while the economic deal is the same, the tax consequences differ. GainCorp is treated as a separate taxpayer, while income or loss generated by LossLLC is passed through to its owners.

Losses are the more important tax feature in the early years of the venture. A startup's tax losses are generated largely by two Code sections, $§ 195$ and $§ 174$. Section 195 requires startups to capitalize expenditures incurred in connection with creating a new business, but it allows taxpayers to elect to amortize those expenses over a relatively short five-year period. ${ }^{33}$ Section 174 goes further, allowing taxpayers to deduct "research and experimental" expenditures in the year in which they are incurred, even if the expenses are expected to produce a product with a long useful life, such as a patentable process or technology. ${ }^{34}$ The term "research and experimental" has been interpreted

company, sometimes a small one; VCs receive a variety of liquidation preferences, dividend rates, conversion ratios, and so on - the form of the investment is usually the same. The VC Fund's investment usually takes the form of convertible preferred stock; the entrepreneur takes the common stock, often subject to vesting requirements, and may also receive stock options. The Fund's preferred stock investment takes place in several stages as the entrepreneur meets the goals set out in the business plan. On the uniformity of VC deal structures, see Ronald J. Gilson \& David M. Schizer, Understanding Venture Capital Structure: A Tax Explanation for Convertible Preferred Stock, at 5 (forthcoming Harv. L. Rev.); Steven Kaplan \& Per Stromberg, Financial Contracting Theory Meets the Real World: An Empirical Analysis of Venture Capital Contracts, National Bureau of Economic Affairs Working Paper No. 7660, at pin (2000). For an overview of the venture capital industry, see Paul A. Gompers \& Josh Lerner, THE VENTURE CAPITAL CyCle (1999). For sample documents, see Michael J. Halloran, Lee F. Benton, Robert V. Gunderson, Jr., Jorge del Calvo, \& Benjamin M. Vandegrift, Venture CAPITAL \& PUBLIC OfFering NEGOTIATION ( 3 d ed. 2002).

The discussion here is limited to venture capital, not private equity generally, as the structure of private equity investments varies to a greater extent. See generally Andrew W. Needham, A Guide to Tax Planning for Private Equity Funds and Portfolio Investments, 94 Tax Notes 1215 (2002) (Part 1 of 2); 94 Tax Notes 1381 (2002) (Part 2 of 2).

${ }^{32}$ On the downside, the VC Fund receives the right to the entire current liquidation value of the startup represented by preferred stock in GainCorp and by the capital interest in LossLLC. See generally William W. Bratton, Venture Capital on the Downside: Preferred Stock and Corporate Control, 100 Mich. L. Rev. 891, 897-901 (2002) (describing preferred stock arrangements regarding control). On the upside, the VC Fund has the right to the first profits of the company and a share of profits beyond that - represented by liquidation preference and conversion rights written in to the terms of the preferred stock in the case of GainCorp, and liquidation and preference rights written in to the operating agreement in the case of LossLLC.

${ }^{33}$ See $\S 195$. In general, a capital expenditures is the cost of acquiring property that has a useful life extending beyond the close of the taxable year. The cost is included in or added to the basis of the acquired property and either recovered over time through depreciation or amortization deductions or recovered when the property is sold. See generally Marvin A. Chirelstein, FedERAL InCOME TAXATION: A GUIDE TO THE LEADING CASES AND CONCEPTS 107 ( $7^{\text {th }}$ ed. 1994).

${ }^{34}$ See $§ 174$. 
broadly to include the costs of salary, rent, and equipment associated with research. ${ }^{35}$ There is also a tax credit for research costs under $\S 41$, which gives qualifying taxpayers a credit for $20 \%$ of their incremental increase in research expenses from prior years above a statutorily-calculated, taxpayer-specific, base amount. ${ }^{36}$ As a result of these Code sections, a startup will generate tax losses within five years that, when added together, nearly equal the amount of money originally contributed to the venture. ${ }^{37}$

The Passthrough Structure enables taxable LPs to take advantage of these tax losses. The operating agreement of LossLLC allocates tax losses to the VC Fund, a limited partnership which is also a passthrough entity for tax purposes. ${ }^{38}$ The VC Fund's partnership agreement then allocates tax losses to LPs in proportion to the amount of money each contributed at the start of the Fund. The LPs realize the tax losses generated by LossLLC in the same year they were incurred and, subject to various restrictions discussed below, use those losses to offset other taxable income.

The C Corp Structure, on the other hand, cannot take full advantage of tax losses generated by the startup. As a corporation, GainCorp traps its tax losses at the entity level and carries them forward as a net operating loss (NOL). The NOL might be used in future years to offset GainCorp's taxable income. Several conditions, however, limit the value of GainCorp's NOL. First, GainCorp might never become profitable, in which case it will never soak up its NOL. Second, even if GainCorp does become profitable and uses the NOL, the value of the tax loss is diminished by the time value of money. A tax loss tomorrow is worth less than a tax loss today. Third, if there is a change in control in GainCorp, as often happens when, for example, a moderately successful startup is sold to

\footnotetext{
${ }^{35}$ See Bankman, Silicon Valley Startups, supra note 3, at 1741; Treas. Reg § 1.174-2(a)(1); Rev. Proc. 2000-50 (setting forth guidelines pertaining to deduction of costs incurred to develop, purchase or lease computer software).

${ }^{36}$ See $\S 41$.

${ }^{37}$ See Bankman, Silicon Valley Startups, supra note 3, at 1743.

${ }^{38}$ Funds are now sometimes organized as LLCs. Many funds, however, prefer to organize as limited partnerships. If an LLC is used there is some uncertainty regarding the corporate law treatment of certain management arrangements commonly employed by funds. See Halloran et al., supra note 32, at 2001 Supp. 2-2 ("To date, there has been limited interest shown by venture capitalists in organizing venture capital funds as LLCs, although this situation is likely to change in time as fund promoters become more comfortable with this new form of legal entity.").. Because the tax treatment is the same and the limited partnership agreements "work," (i.e. achieve the goals they are designed to achieve), there is little pressure to adopt a new form.
} 
a trade buyer, ${ }^{39} \S 382$ restricts the acquiror's use of NOLs, depressing the value of the tax asset. $^{40}$

Tables 1 through 3 below compare the effects of the Passthrough Structure versus the C Corp Structure on pre-tax and after-tax returns of taxable investors in startups. The tables display three scenarios:

- the Strikeout, in which the VC Fund puts in $\$ 3$ million in year one and the startup is sold in year six for $\$ 500,000$, generating a net pre-tax loss of $\$ 2.5$ million;

- the Base Hit, in which the VC Fund puts in $\$ 3$ million in year one and $\$ 3$ million in year four, and the startup is sold in year six for $\$ 14$ million, with $\$ 12$ million of the proceeds going to the fund, generating a net pre-tax gain of $\$ 6$ million for the Fund, and

- the Home Run, in which the VC Fund puts in \$3 million in years one, four, and five, and the startup IPOs in year six with a market capitalization of $\$ 300$ million, and the Fund sells its stake for $\$ 75$ million, generating a net pre-tax gain of $\$ 66$ million for the Fund. ${ }^{41}$

I have (for the moment) adopted a series of common assumptions, each of which favors the Passthrough Structure: (1) zero transaction costs, (2) full use of tax losses by taxable LP investors at a 40\% marginal tax rate, (3) zero value or discounted value of GainCorp's NOL, and (4) no § 1202 exclusion or $§ 1045$ rollover of capital gains tax on the sale of GainCorp stock, which I assume is taxed at an effective rate of $20 \%$. I use a discount rate of $6 \%$ to calculate net present value. Also note that the LP investors' upside return is

\footnotetext{
${ }^{39}$ A "trade buyer" is a larger competitor in the same general industry. A computer chip startup, for example, might look to be acquired by Intel or Texas Instruments.

${ }^{40}$ See $\S 382$. See Richard L. Parker, The Innocent Civilians in the War Against NOL Trafficking: Section 382 and the High-Tech Start-Up Companies, 9 Va. Tax Rev. 625 (1990); see also Mark Campisano \& Roberta Romano, Recouping Losses: The Case for Full Loss Offsets, 76 Nw. U. L. Rev. 709 (1981).

${ }^{41}$ The baseball metaphor is an unfortunate cliché, but I employ it here because it is the metaphor commonly used in the venture capital industry. A single is often used to denote a $100 \%$ return on investment, a double for a $2 x$ return, and a home run or grand slam for greater returns. See also Bankman, Silicon Valley Startups, supra note 3, at 1764-65 ("'The industry has a home run mentality,' stated a prominent venture capitalist in response to a similar inquiry into the lack of attention to tax benefits.' Others interviewed expressed like sentiments, often relying on the same baseball metaphor.").
} 
reduced by $20 \%$ to account for the "carried interest" allocated to the VC professionals who manage the Fund. ${ }^{42}$

\section{TABLE 1: STRIKEOUT - RETURN FOR TAXABLE LP \\ (IN \$MILLIONS)}

\begin{tabular}{|c|c|c|c|c|c|c|c|}
\hline Strikeout & Year 1 & Year 2 & Year 3 & Year 4 & Year 5 & Year 6 & NPV \\
\hline LossLLC Pre-tax & -3 & 0 & 0 & 0 & 0 & .5 & -2.48 \\
\hline LossLLC After-tax & -2.28 & .12 & .12 & .12 & .12 & .4 & $\mathbf{- 1 . 4 8}$ \\
\hline GainCorp Pre-tax & -3 & 0 & 0 & 0 & 0 & 0.5 & -2.48 \\
\hline GainCorp After-tax & -3 & 0 & 0 & 0 & 0 & 1 & $\mathbf{- 2 . 1 3}$ \\
\hline
\end{tabular}

Strikeout. On these assumptions LossLLC is clearly superior to GainCorp for taxable investors. ${ }^{43}$ Because LossLLC passes through tax losses, the net present value of the \$3 million investment in LossLLC is negative \$1.48 million, while the net present value of the \$3 million invesment in GainCorp is negative \$2.13 million. Either investment generates a net loss, but the tax benefits of the Passthrough Structure ease the pain for investors in LossLLC. The difference in value reflects both the time value of the tax losses and the character of the loss; LossLLC's investors capture the value of the tax losses in years one through five at ordinary income rates; GainCorp's investors capture the tax loss in year six at capital gains rates.

TABLE 2: BASE Hit - RETURN FOR TAXABLE LP

\begin{tabular}{|c|c|c|c|c|c|c|c|}
\hline Base Hit & Year 1 & Year 2 & Year 3 & Year 4 & Year 5 & Year 6 & NPV \\
\hline LossLLC Pre-tax & -3 & 0 & 0 & -3 & 0 & 12 & 3.25 \\
\hline LossLLC After-tax & -2.28 & .12 & .12 & -1.68 & .12 & 8.64 & $\mathbf{2 . 9 1}$ \\
\hline GainCorp Pre-tax & -3 & 0 & 0 & -3 & 0 & 12 & 3.25 \\
\hline GainCorp After-tax & -3 & 0 & 0 & -3 & 0 & 9.84 & $\mathbf{1 . 7 3}$ \\
\hline
\end{tabular}

Base Hit. Using the same LossLLC-favorable assumptions, LossLLC is also superior to GainCorp in the Base Hit scenario. ${ }^{44}$ The net present value of the taxable

\footnotetext{
${ }^{42}$ The term "carry" or "carried interest" derives from the fact that the VCs' upside is generated from capital contributed by others; if the Fund performs well, the LPs "carry" the VCs along for the ride.

${ }^{43}$ For tax-exempt investors, the return is the same either way.

The assumptions for the Strikeout scenario are as follows. In year one, a $\$ 3$ million investment is made, and in year six, the investment is sold for $\$ 500,000$. I assume a pre-tax loss of $\$ 1.8$ million in year one, followed by $\$ 300,000$ in years two, three, four, and five. In LossLLC, the investment now has a basis of zero, and in year six is sold at a gain of $\$ 500,000$; I assume a $20 \%$ capital gains rate.

${ }^{44}$ The assumptions for the Base Hit scenario are as follows. In year one, a $\$ 3$ million investment is made. In year 4 , another $\$ 3$ million is invested. In year six, the investment is sold for $\$ 12$ million. I assume a pre-tax loss of $\$ 1.8$ million in year one, $\$ 300,000$ in years two and three, $\$ 3,300,000$ in year four (i.e. that the new investment money is immediately used), and $\$ 300,000$ in year five. Once again, all the basis is
} 
LPs' investment in LossLLC is $\$ 2.91$ million, versus $\$ 1.73$ million in GainCorp. As in the Strikeout scenario, the present value of the tax losses significantly improves the aftertax return for taxable LPs.

TABLE 3: HOME RUN - RETURN FOR TAXABLE LP

\begin{tabular}{|c|c|c|c|c|c|c|c|}
\hline Home Run & Year 1 & Year 2 & Year 3 & Year 4 & Year 5 & Year 6 & NPV \\
\hline LossLLC Pre-tax & -3 & 0 & 0 & -3 & -3 & 75 & 45.42 \\
\hline LossLLC After-tax & -2.28 & .12 & .12 & -1.68 & -1.56 & 51.24 & $\mathbf{3 0 . 6 7}$ \\
\hline GainCorp Pre-tax & -3 & 0 & 0 & -3 & -3 & 77 & 46.84 \\
\hline GainCorp After-tax & -3 & 0 & 0 & -3 & -3 & 52.52 & $\mathbf{2 9 . 5 8}$ \\
\hline
\end{tabular}

Home Run. Here, LossLLC is only slightly superior to GainCorp, even with all the LossLLC-favorable assumptions: An investment in LossLLC has a net present value of $\$ 30.67$ million versus $\$ 29.58$ million for GainCorp. The tax savings pale in comparison to the gross amount realized. ${ }^{45}$

60-30-10 Scenario. No one knows at the outset whether a venture will succeed or not, but it is helpful to assign percentage values estimating the likelihood of success. ${ }^{46}$ Table 4 below shows the net present value of the investment opportunity in LossLLC or GainCorp, using a realistic 60-30-10 scenario (60\% chance of strikeout, $30 \%$ base hit, $10 \%$ home run). ${ }^{47}$

used up in LossLLC, and the gain in year six is taxed at a $20 \%$ capital gain rate. One further complication: the pre-tax gain is also a "pre-carry" gain; it is reduced by $20 \%$ to reflect the carried interest of the VCs, then reduced by the $20 \%$ capital gains rate to reach the final after-tax return.

${ }^{45}$ The assumptions for the Home Run scenario are as follows. In years one, four, and five, the Fund invests $\$ 3$ million. In year six, the investment is sold for $\$ 75$ million. The sales price for GainCorp is slightly higher, reflect the value of the $\$ 9$ million NOL. Again, the "pre-tax" figure is also "pre-carry"; the aftertax return reflects the reduction for the carried interest of the VCs.

${ }^{46}$ In one sample, which included later stage financings as well as the early stage financings that I am focused on here, 50 percent of the total return was generated by only 6.8 percent of the investments; over a third of the investments resulted in partial or total loss. See Theodore Baums \& Ronald J. Gilson, Comparative Venture Capital Contracting, Working Paper (September 2001) (on file with author); Venture Economics, Exiting Venture Capital Investments (1988). In the tech bubble of 1999 and 2000, the variability was even greater as some companies were given "nosebleed" valuations by an overheated stock market. See generally Douglas J. Cumming \& Jeffrey G. MacIntosh, Venture Capital Exits in Canada and the United States (2001) (Working Paper available on ssrn.com) (describing breakdown of exits). During the 1990s, the percentage of IPOs increased dramatically, resulting in something like a 50-25-25 breakdown; since the tech bubble burst, the percentage of IPOs has dropped back to $10 \%$ or fewer.

${ }^{47}$ In 2001 there were just 37 venture-backed IPOs, compared to 226 in 2000 and 257 in 1999. The number of venture-backed M\&A transactions, however, increased to 322 from 299 in 2000 and 234 in 1999. See National Venture Capital Association 2002 Yearbook 81 (Thomson Financial Venture Economics 2002). Successful exits are therefore still taking place, albeit at lower valuations. The net IRR figure I use for GainCorp, $18 \%$, is, if anything, low by historical standards. Although venture funds lost $27 \%$ on average 


\section{TABle 4: Net PRESENT VALUe OF INVESTMENT}

\begin{tabular}{|c|c|}
\hline 60-30-10 Breakdown & NPV \\
\hline LossLLC After-tax & 3.05 \\
\hline GainCorp After-tax & 2.20 \\
\hline
\end{tabular}

The tables above rely on several key assumptions, including full use of tax losses by LPs, a $20 \%$ capital gains tax rate, and zero transaction costs. Given these passthrough-favorable assumptions, the LossLLC structure generates a superior after-tax return, as expected (\$3.05 million vs. \$2.20 million). Calculated in terms of internal rate of return, the investment in LossLLC generates an expected IRR of $26 \%$, vs. $18 \%$ for GainCorp. If this were the whole story, we would expect startups to opt for the Passthrough Structure in order to lower the startup's financing costs. But further analysis shows that these assumptions are unrealistic. With more realistic assumptions, the balance ultimately tilts in favor of the C Corp Structure.

\section{Why Partnership Tax Losses Are Less Attractive Than They Seem}

When a startup organized as a partnership generates tax losses, the value of those losses depends on whether the LP investors have taxable income to offset and whether the tax Code allows the LPs to use the losses immediately. Of the four major classes of venture capital investors - U.S. individuals, U.S. corporations, tax-exempt investors, and foreign investors - only a subset of one class, widely-held U.S. corporations with current tax liability, can use the losses fully and is likely to prefer the Passthrough Structure. For other investors, the Passthrough Structure is actually disadvantageous, as it either creates new tax liabilities or eliminates tax benefits available in the C Corp Structure. Moreover, the VC professionals who structure the deals so not share in the losses, so they have little reason to pay attention to the tax effects of losses.

in 2001 , the 3 year average IRR is $49.3 \%$, the 5 year average IRR is $36 \%$, the 10 year average IRR is $27 \%$, and the 20 year average IRR is $18 \%$. See id. at 14. 


\section{A. The VC Professionals: Indifferent to Losses}

The key potential advantage of the Passthrough Structure is the impact of tax losses on the LP investors. But it may be more important to consider first the impact of losses on the venture capital professionals (VCs) who manage the funds. VCs hold a substantial economic stake in the funds they manage, but only on the upside. In a typical partnership agreement with LP investors, the VCs contribute just one percent of the capital to the fund but receive a carried interest of 20\%: that is, they receive $20 \%$ of the profits of the entire fund despite only putting up a small amount of money. ${ }^{48}$ The carry gives the VCs a large share of the upside potential but almost none of the downside. The tax losses generated by the Passthrough Structure therefore have almost no value to the VCs. ${ }^{49}$

The VCs' attitude toward tax losses is significant. The VCs dictate the deal structure at the point of initial investment, even though the startup's founders technically control the startup. VCs are usually much more experienced and sophisticated in structuring investments than the founders, and they tend to be the dominant force in negotiations, especially in legal matters. As a result, agency costs - the tendency for agents investing other people's money to do so in a way that enhances their own personal benefit - partly explains why the Passthrough Structure is unpopular. ${ }^{50}$ The advantages of the Passthrough Structure inure almost entirely to the benefit of LPs; the VCs, acting

\footnotetext{
${ }^{48}$ To be precise, the VCs receive $20.8 \%$ of the profits; the extra $0.8 \%$ is generated by the $1 \%$ of capital contributed by the VCs multiplied by the $80 \%$ of profits not already allocated to the VCs.

${ }^{49}$ The arrangement is roughly economically equivalent to giving the VCs an option to buy $20 \%$ of the fund at a strike price of zero. Like any option, this incentivizes the VCs to make riskier investments than they would if they owned a substantial stake in the fund outright and also therefore shared in the losses. On the impact of options on the behavior of managers, see, e.g., Calvin H. Johnson, Stock Compensation: The Most Expensive Way to Pay Future Cash, 52 SMU L. Rev. 423, 443 (1999) ("Stock options, however, create truly bizarre incentives for management to squelch dividends and seek out risk, even though it damages shareholder wealth.”).

${ }^{50}$ Classic works on the agency costs problem in corporate governance include Adolf A. Berle \& Gardiner C. Means, The Modern Corporation and Private Property (rev. ed. 1991); Frank H. Easterbrook \& Daniel R. Fischel, The Economic Structure of Corporate Law (1991); Mark J. Roe, Strong Managers, Weak Owners: The Political Roots of American Corporate Finance (1994).
} 
as agents for the LPs, ignore this benefit in favor of their own interests. ${ }^{51}$ To my knowledge, prior commentators have not taken this factor into account. ${ }^{52}$

Agency costs cannot fully account for the VCs' behavior. The market for venture capital is competitive enough that we would not expect the attitude of the VCs alone to explain the general indifference to tax losses. Agency costs pose the greatest problem when the principal has difficulty observing or monitoring the agent's behavior. Here, the choice of organizational form is an esoteric problem but not impossible to understand. If the Passthrough Structure truly generated significantly better after-tax returns for LPs, some savvy VCs might choose that structure and find LPs who were willing to divide the extra gains by increasing the VCs' carried interest or management fee. ${ }^{53}$ Instead, the $\mathrm{C}$ Corp Structure remains the industry standard. The entrenchment of the C Corp Structure might be due in part to the fact that tax losses are a hard sell and difficult to employ as a bargaining chip. The structural benefits of flowthrough taxation are not always intuitive and may be difficult to discern, especially for investors who are unfamiliar with tax arcana. But indeed if agency costs were the only factor, one would expect sophisticated investors to overcome the problem. ${ }^{54}$

In sum, agency costs are a factor encouraging VCs to ignore tax losses but standing alone cannot crack the puzzle. More important, as I discuss next, is that the

\footnotetext{
${ }^{51}$ Cf. Michael Klausner, Institutional Shareholders' Split Personality on Corporate Governance: Active in Proxies, Passive in IPOs, at 10 (Working paper, 2001) (on file with author) (noting possibility that VCs may push for pro-management terms at IPO stage to enhance reputation with management, even though those terms hurt LP institutional investors).

${ }^{52}$ On agency costs affecting another aspect of venture capital, see Joseph Bankman \& Marcus Cole, The Venture Capital Investment Bust: Did Agency Costs Play a Role? Was It Something Lawyers Helped Structure?, 77 Chi.-Kent L. Rev. 211, 225 (2002) (discussing costs as possible explanation for continued investment in technology companies after the March 2000 NASDAQ collapse).

${ }^{53}$ See Gompers \& Lerner, Venture Capital Cycle, supra note 32, ch. 4 (analyzing LP agreements and concluding that while carried interest percentages are held constant, management fees vary depending on the ability and experience of the VCs).

${ }^{54}$ An additional agency costs factor may have helped cement the status quo, especially in the late 1990s: law firms that wish to make equity investments in their clients may prefer the C Corp Structure, as becoming a "partner" in the client's business venture may create a greater appearance of impropriety than merely holding common stock or options in a corporate client. The relevant conflict of interest rules, however, do not rely on a per se approach or draw distinctions based on formalities, but rather look to the degree to which the law firms' independence might be compromised. See generally John S. Dzienkowski \& Robert J. Peroni, The Decline in Lawyer Independence: Lawyer Equity Investments in Clients, 81 Tex. L. Rev. 405 (2002).
} 
potential market for these tax losses is quite small: tax rules make losses attractive to only a small subset of potential LP investors.

\section{B. Individual Investors: Passive Loss Constraints}

Individuals make up a relatively small portion of the venture capital investor pool. ${ }^{55}$ The securities laws exclude many potential investors by limiting the eligibility of individuals to "accredited investors" who have annual income in excess of $\$ 200,000$ or net worth in excess of $\$ 1,000,000 .^{56}$ The securities laws are not the only limiting factor, however: special tax rules enacted in 1986 discourage venture capital investment by individuals, including high net worth individuals exempt from securities laws restrictions.

In 1986 Congress enacted the passive loss rules of $\S 469$ as part of an effort to shut down abusive tax shelters. ${ }^{57}$ An unintended consequence of this legislation was to make passive investing in partnerships a tax-disfavored activity, even for "real" deals not generally considered abusive. ${ }^{58}$ In the absence of $\S 469$, individuals would be permitted to take passive losses to offset ordinary income. Section 469 disallows current deductions for losses generated by passive activities, except to the extent the taxpayer has passive income. ${ }^{59}$ Taxpayers may use passive losses to offset ordinary non-passive income, but only at the termination of the venture, thus removing the timing advantage which is key to traditional tax sheltering activity. For purposes of $\S 469$, passive activities are defined as activities which involve the conduct of a trade or business in which the taxpayer does not materially participate. ${ }^{60}$ The rules for determining what constitutes "material" participation are complex. ${ }^{61}$ Absent unusual circumstances,

\footnotetext{
${ }^{55}$ In 2001, 9\% of capital commitments came from individuals and families. See 2002 NVCA Handbook, supra note 45 , at 23 . This figure appears to include family trusts.

${ }^{56}$ See 17 C.F.R. $\S 230.501$ (a)(5), (6) (Rule 501 of Regulation D).

${ }^{57}$ See Staff of the Joint Comm. on Tax'n, 100th Cong., 1st Sess., General Explanation of the Tax Reform Act of 1986, at pin (Comm. Print 1987).

${ }^{58}$ See Joseph Bankman, The Case Against Passive Investments: A Critical Appraisal of the Passive Loss Restrictions, 42 Stan. L. Rev. 15 (1989) (hereinafter Bankman, Passive Loss Rules).

${ }^{59}$ See $\S 469$.

${ }^{60}$ See $\S 469(a)(1), 469(c)$.

${ }^{61}$ See Bankman, Passive Loss Rules, supra note 54, at 24 (noting that the restrictions "comprise one of the more complicated areas of the tax law").
} 
however, the passive loss rules prevent limited partners in $\mathrm{VC}$ funds from immediately using the losses, as LPs do not normally help manage the portfolio companies in any significant way. ${ }^{62}$ The tax losses in the Passthrough Structure flow through to the VC Fund and then to the LPs, but individuals may not use those losses immediately to offset taxable income from non-passive activities. The passive losses are instead "suspended" or carried forward and may be used only to offset passive income, or may be added to basis when the LP's interest in the passive activity is sold. ${ }^{63}$ The present value of the tax loss is thereby significantly diminished. ${ }^{64}$ For individual investors, the passive loss rules suffocate the very purpose of the Passthrough Structure by eliminating the benefit of the flowthrough of tax losses.

\footnotetext{
${ }^{62}$ See Daniel N. Shaviro, Passive Loss Rules, BNA Tax Mgmt. Portfolio 549-2 ${ }^{\text {nd }}$ at 21 (2000) (discussing material participation standard). The VCs, unlike the LPs, would have a very strong argument that their oversight of portfolio companies constitutes material participation. But under the terms of the economic deal, VCs are usually allocated $20 \%$ of the gains and just $1 \%$ of the losses, so the tax losses matter little to the VCs. Similarly, the entrepreneurs who manage the portfolio company would not be constrained by the passive loss rules, but would also likely have an economic arrangement which effectively allocates to the only gains and not losses.
}

Angel investors are often U.S. high-net-worth individuals, and the companies that they invest in are sometimes structured as partnerships. Although the involvement of angel investors varies widely, many avoid the passive loss rules because they often sit on the boards of directors of the companies they invest in and provide advice to the founders and management, creating a good argument for "material participation," depending on the facts and circumstances. The availability of the losses to angel investors helps explain why at the pre VC stage, many companies are structured as partnerships, while at the VC stage, they convert to corporations.

${ }^{63}$ See $\S \S 469(\mathrm{~d})(1), 469(\mathrm{~g})$. Some wealthy individuals with passive losses do have (or seek out) investments that create passive income. Such passive income generators, appropriately called PIGs, would benefit from the passthrough structure. For many taxpayers, however, it is difficult to convert nonpassive income - e.g., salary - income passive income. See Daniel Shaviro, Selective Limitations on Tax Benefits, 56 U. Chi. L. Rev. 1189, 1256 (1989) ("For many taxpayers, such as professionals and salaried employees, it is not feasible to convert significant amounts of compensation income into passive income. ... Some taxpayers, however, such as entrepreneurs who own and operate a variety of businesses, may have considerably less difficulty creating passive income and nonpassive losses; but the passive loss rules probably reduce substantially the pool of investment dollars that are available for investments designed to produce tax losses.")

${ }^{64}$ Eliminating the time value of the tax losses is enough to discourage classic "tax shelter" activity in which individuals are willing to incur long-term economic losses to achieve short-term tax benefits. 


\section{Foreign Investors: ECI Concerns}

As a practical matter, foreign investors cannot benefit from the tax losses in the Passthrough Structure. Foreign individuals are subject to the passive loss rules, so that just as with U.S. individuals, the flowthrough of tax losses has no significant benefit. For foreign corporations that invest in VC funds, two primary concerns make the Passthrough Structure unattractive: (1) the concept of effectively connected income, or "ECI", and (2) the branch profits tax of $\S 884 .{ }^{65}$

A complex set of rules governs the taxation of foreign corporations that invest in U.S. companies. Foreign corporations that sell stock in a U.S. corporation are generally exempt from U.S. capital gains tax on any appreciation in that stock. ${ }^{66}$ So long as a foreign corporation is not engaged in a U.S. trade or business by operating a U.S. subsidiary or unincorporated U.S. branch, capital gains from investment in the U.S. are not taxed in the U.S., although the corporation may owe tax in its home jurisdiction. This general exemption for capital gains encourages foreign investment in U.S. securities and prevents double taxation across different jurisdictions. ${ }^{67}$

To ensure that foreign corporations that operate a business in the U.S. do not enjoy an advantage over U.S. corporations, foreign corporations are taxed in the U.S. on income which is "effectively connected" with a U.S. trade or business. ${ }^{68}$ The Passthrough Structure, which makes intermediate entities in the structure transparent for tax purposes, creates a situation where the tax law treats the LPs at the top of the structure as if they directly own a pro rata portion of the startup's business. If a startup is organized as a partnership for tax purposes, and the startup is engaged in a U.S. trade or business, then each foreign LP of the VC Fund investing in the startup is deemed to be engaged in the startup's trade or business. ${ }^{69}$ Under $\S \S 871$ or 881 , the foreign LP investor

\footnotetext{
${ }^{65}$ Professor Bankman did not focus on the effect of tax rules in foreign investors, perhaps because fewer foreign companies invested in the U. S. venture capital market in 1994 than today.

${ }^{66}$ See $\S 871$ (a)(2) (imposing tax on foreign persons only if present in the U.S. for at least 183 days during the taxable year).

${ }^{67}$ See generally Fred B. Brown, Federal Income Taxation of U.S. Branches of Foreign Corporations: Separate Entity or Separate Rules, 49 Tax L. Rev. 133, 145 (1993) (describing ECI rules).

${ }^{68}$ See $\S \S 872(a)(2), 882(a)(1)$.

${ }^{69}$ See $\S 875(1)$; see also $\S 702$ (b); Treas. Reg. § 1.702-1(b) (noting that the character of partnership gains allocated to each partner under $§ 702$ (a) is determined at the partnership level).
} 
must pay U.S. tax on the "effectively connected income," or ECI, generated by that portion of the business. Recognizing ECI is problematic because many foreign investors want to avoid the U.S. tax system altogether, including the obligation to file a U.S. tax return. ${ }^{70}$ The concern is serious enough that many fund agreements require the VCs to promise to avoid generating ECI. ${ }^{71}$

The branch profits tax is an additional concern for foreign corporations. Assuming that the startup generates tax losses in the early years of the venture, the possibility of ECI would appear to be a red herring, since tax is due only to the extent that there is taxable income, not loss. But $\S 884$, which imposes a branch profits tax on U.S. divisions of foreign corporations, uses the ECI concept to make exiting the Passthrough Structure difficult for foreign LPs. Under $§ 884$, a foreign corporation must pay tax on deemed repatriations of earnings by U.S. divisions of foreign corporations. ${ }^{72}$ Because the Passthrough Structure causes the LPs to be treated as if they owned a portion of the startup's business directly, $\S 884$ treats the startup as if it were a branch of the foreign corporation. When the appreciation in the value of the startup is realized through the $\mathrm{VC}$ Fund's sale of its interest in the startup, the foreign LP's pro rata portion is subject to the branch profits tax at a marginal rate of up to 54.5 percent. ${ }^{73}$ If, on the other hand, the portfolio company were organized as a C Corporation, the foreign investor would not be treated as engaged in a U.S. trade or business and would not be subject to the branch profits tax of $\S 884$. Instead, the foreign LP would take advantage of the usual foreign investor exemption for capital gains. ${ }^{74}$

\footnotetext{
${ }^{70}$ See Andrew R. Bronstein, Mitchell Presser \& David E. Shapiro, Private Equity Funds: Legal Analysis of Structural, Erisa and Securities Issues, 1276 PLI / Corp 7, 17 n.23 (2001) (noting that foreign private equity investors prefer to use blocker corporation that files U.S. return).

${ }^{71}$ See Halloran et al., supra note 32, at 1-29.

${ }^{72}$ See $\S 884$.

${ }^{73}$ See Needham, supra note 32, at 1231 . For foreign individual LPs, the sale of the partnership is treated as a deemed sale of a pro rata share of partnership interests, resulting in ECI gain. See Rev. Rul. 91-32, 19911 C.B. 107. But see Kimberly Blanchard, "Rev. Rul. 91-32: Extrastatutory Attribution of Partnership Activities to Partners," 1776 Tax Notes 1331 (1997) (criticizing IRS's use of aggregate theory of partnerships in this context). The basic policy principle that seems to be at stake here is whether business profits generated in the U.S. must be subject to at least one level of tax.

${ }^{74}$ Foreign investors are usually taxed in the U.S. only on income that is ECI or certain types of fixed passive income (FDAP income) subject to withholding, and real estate investments.
} 
Careful tax planning can enable foreign corporations to invest in U.S. venture capital funds that invest in portfolio companies structured as partnerships. A "blocker" entity can be inserted into the structure to block the passthrough effects of the partnership form; the passthrough of income and loss extends up the organizational chain only until there is a non-transparent taxpayer. If a blocker entity intervenes, the blocker entity traps income or loss at that level, the foreign LP's income from the startup is not "effectively connected," and the branch profits tax does not apply. Because the blocker entity traps not just gains but losses as well, however, the tax losses are not passed through to the investor for its immediate benefit. ${ }^{75}$ Thus, the necessary blocker entity structure eliminates the benefit of the tax losses that would have motivated the use of the Passthrough Structure in the first place. For the sake of simplicity in deal planning, the C Corp Structure is preferred. ${ }^{76}$

\section{Tax-Exempt Investors: UBTI Concerns}

Tax-exempt entities such as pension funds and university endowments comprise the largest investor class in the venture capital industry. ${ }^{77}$ Such entities do not have to pay tax on investment income. They do, however, have to pay tax on unrelated business taxable income, also known as "UBTI" ${ }^{78}$ Because deemed ownership of an operating business generates unwanted UBTI, tax-exempt investors want to avoid being treated as if they own a portion of the startup's business. ${ }^{79}$

Tax-exempt entities prefer to receive returns on their investments in the form of returns not taxable to them (i.e., most investment interest, dividends, and capital gains), and they scrupulously avoid deal structures that pass through a pro rata portion of the ordinary income from a business, which is taxable as UBTI. Because the Passthrough

\footnotetext{
${ }^{75}$ See Needham, supra note 32, at 1386.

${ }^{76}$ There is also a possibility that the blocker entity will not be respected (i.e. treated as a mere shell). See Needham, supra note 32, at pin.

${ }^{77}$ See 2002 NVCA Yearbook, supra note 45 , at 23 (reporting that $42 \%$ of investors are private and public pension funds, and an additional $22 \%$ are endowments and foundations).

${ }^{78}$ See $\S 511$.

${ }^{79}$ See $\S 512(\mathrm{c})(1)$. Section 514 also recasts interest, dividends and capital gains that are otherwise exempt as UBTI if the underlying property is debt-financed (whether the investment is leveraged at the tax-exempt entity level or the partnership level). Unlike hedge funds, which are frequently leveraged, venture capital funds usually are not, making the debt-financed exception to the UBTI rule less important in this context.
} 
Structure is transparent for tax purposes, tax-exempt LP investors are treated as if they own a pro rata portion of the startup's business directly, just as with foreign investors, and any income generated by the business is UBTI. Tax-exempt investors go to great lengths to ensure that they have no reportable UBTI at all, as having even a small amount of UBTI is thought to greatly increase the risk of audit. Because the tax Code treats LPs in the Passthrough Structure as directly engaged in the business of the startup, and the startup's business is unlikely to be consistent with the § 501(c)(3) status of the organization, it is sometimes said that investing in numerous portfolio companies structured as partnerships could potentially endanger the tax-exempt status of the entire organization. ${ }^{80}$ While this result would be unlikely, it is safe to say that tax-exempt investors have a valid reason to prefer the simpler C Corp Structure. ${ }^{81}$

Finally, to make a rather obvious point, tax-exempt investors do not care about tax losses, since they do not have tax liability which could be offset by such losses, except in the unusual case in which they have UBTI from other investments. The sole concern for most tax-exempt investors is the pre-tax return on the investment. To the extent that tax-exempt investors think about tax consequences at all, it is to ensure that they do not recognize any UBTI. ${ }^{82}$

\section{E. Corporate Taxable Investors}

There is one key class of investors not subject to any significant tax law restrictions: Corporate LPs. The tax losses generated by the Passthrough Structure are potentially valuable to Corporate LPs; widely-held corporations are not subject to the passive loss rules of $\S 469$, and many corporations have current tax liability that they would like to shelter. ${ }^{83}$ Some corporations do invest in startups, and one would expect

\footnotetext{
${ }^{80}$ It is worth noting that absent the fear of audit, the partnership structure would make sense for some foreign and tax-exempt investors, as the early losses of startups could be used to offset other ECI/UBTI gains subject to U.S. tax on a net basis. See Needham, supra note 32, at 1231 n.96.

${ }^{81}$ As with foreign investors, a "blocker" structure can be used to try to eliminate UBTI, eliminating both the disadvantage and advantage of the Passthrough Structure.

${ }^{82}$ In Silicon Valley Startups, Professor Bankman noted the effect of the Passthrough Structure on taxexempt investors but argued that if the Passthrough Structure were adopted, corporate taxable investors might fill in the gap. I discuss this argument in the next section, infra text accompanying notes 78-86.

${ }^{83}$ See $\S \S 469$ (a)(2)(B), (a)(2)(C) (applying passive loss rules only to closely-held C corporations and to personal service corporations).
} 
such investors to push for the investment to be structured in the most tax-efficient form. For example, Intel owns several funds which invest strategically in startups. ${ }^{84}$ When Intel invests in a startup organized as a partnership, and the startup generates tax losses in the early years of the venture, Intel may use the tax losses generated from that investment to offset taxable income from its normal business operations. If, on the other hand, the startup is organized as a corporation, and Intel's investment falls short of the $80 \%$ threshold needed to bring the startup within Intel's consolidated tax return, Intel cannot benefit from the startup's losses. ${ }^{85}$ Why, then, are Corporate LPs content with the C Corp Structure?

Three non-tax factors explain why corporate investors traditionally play a small role in venture capital investing and why, when they do invest in venture capital, they prefer the C Corp Structure: 1) accounting treatment, 2) the passive nature of the relationship between the LPs and the startup, and 3) the networking bond between the VCs and tax-exempt LPs.

Corporate managers focus heavily on reported GAAP earnings, not after-tax returns. ${ }^{86}$ A corporate taxable investor in the Passthrough Structure would see an increase in after-tax earnings compared to the C Corp Structure, but the losses which generate tax savings would depress reported earnings on the corporate investor's income statement to shareholders. ${ }^{87}$ If the startup is organized as a corporation, a minority investor must use the "equity method" - where losses are immediately reflected on the income statement - only if the interest exceeds $20 \%{ }^{88}$ But if the corporate investor's interest is less than $20 \%$, as would usually be the case for a corporate LP investing in a startup though a VC Fund, then the corporate LP may use the "cost method," in which

\footnotetext{
${ }^{84}$ See Intel Capital - Intel Strategic Investment Program, http://www.intel.com/capital/index.htm (site last visited August 6, 2002). Interestingly, even the startups in Intel's portfolio are structured as $C$ Corporations, even though Intel could benefit from the tax losses and would not be constrained by the passive loss rules. See http://www.intel.com/capital/portfolio/intelcapital-portfoliolist.pdf (site last visited August 6, 2002) (listing portfolio companies). Because many of Intel's investments are syndicated, however, it is possible that the C Corp Structure is chosen to ensure the participation of other elite VC funds who rely on pension funds and other tax-exempt investors.

${ }^{85}$ See $\S 1501$ et seq..

${ }^{86}$ See Bankman, Silicon Valley Startups, supra note 3, at 1763.

${ }^{87}$ See Bankman, Silicon Valley Startups, supra note 3, at 1764

${ }^{88}$ APB 18.
} 
gains or losses are not recognized on the income statement until the investment is sold. And so in the usual case where a startup suffers early losses that may be offset by later gains, the cost method results in a prettier picture for shareholders and analysts. If, on the other hand, the startup is organized as a partnership, then an interest of just 3-5\% requires use of the equity method. ${ }^{89}$ The startup's losses depress reported earnings even though the true value of the investment is the same regardless of form.

Professor Bankman has noted that this disparity in accounting treatment leads to the conclusion that corporate managers "appear to sacrifice tax benefits at the altar of reported earnings." ${ }^{90}$ As he explains, this conclusion is difficult to reconcile with the strong or semi-strong form of the efficient market hypothesis. ${ }^{91}$ A reduction in reported earnings caused by investment in the Passthrough Structure should, in theory, be disregarded by analysts and sophisticated investors setting the stock price. But we know from recent history that investors are often too willing to focus on reported earnings, and their ability to look through financial reporting is very much in question. ${ }^{92}$ To be sure, blaming accounting treatment for a tax-inefficient strategy is troubling, as one would hope that there might be some corporate managers willing to explain the deal structure to analysts in order to achieve the greater goal of maximizing after-tax returns. ${ }^{93}$ But given

\footnotetext{
${ }^{89}$ See EITF Topic D-46, Accounting for Limited Partnership Investments.

${ }^{90}$ See also Joseph Bankman \& Ronald Gilson, Why Start-Ups, 51 Stan L. Rev. 289, 299-306 (1999) (describing difficulties corporations encounter when bidding for employees' new ideas).

${ }^{91}$ The efficient market hypothesis posits that a market is efficient if it is impossible to make a profit by trading based on the basis of a information set; the weak form of EMH uses past prices as the information set; the semi-strong form uses all publicly available information as the information set, and the strong form uses all information, including private and insider information. See Jeffrey N. Gordon \& Lewis A Kornhauser, Efficient Markets, Costly Information, \& Securities Research, 60 N.Y.U. Law Rev. 761, 771 n.19 (1985) (defining forms of EMH).

${ }^{92}$ See, e.g., Jeffrey N. Gordon, What Enron Means for the Management and Control of the Modern Business Corporation: Some Initial Reflections, 69 U. Chi. L. Rev. 1233, 1236 (citing an analyst describing Enron as a "faith" stock); Victor Fleischer, Enron's Dirty Little Secret: Waiting for the Other Shoe to Drop, 94 Tax Notes 1045, 1047 (2002) (noting that some of Enron's accounting gimmicks were "hiding in plain sight").

${ }^{93}$ There is also anecdotal evidence that VCs don't like to deal with corporate LPs. One venture capitalist explained that corporate LPs try to "meddle" with the fund's investment decisions and, moreover, often aren't very good at understanding the marketplace for new products. Tax-exempt investors, on the other hand, tend to be more passive and spread out their investments across many different VC funds, reducing their anxiety level about each particular investment and making life easier for the $\mathrm{VC}$ professionals managing the fund.
} 
the real world importance of reported earnings, the accounting treatment of the Passthrough Structure is a non-trivial factor.

The passive nature of the relationship between the LPs and the startup is a second nontax factor that discourages corporate investors from entering VC-managed funds. Corporate managers like to take an active role in their investments, based on their expertise in the corporations' underlying business. Corporations invest in startups, only when they believe they can create value by taking on an active role in advising the startup, thus assuming a role usually performed by the VCs. The presence of the VCs, then, makes little sense, as it simply adds another layer of complexity to the management structure. Empirical results show that this logic holds up in the real world: corporate venture investments perform on par with noncorporate investments only when there is a strategic fit between the corporate investor and the startup. ${ }^{94}$

A third nontax factor that discourages VCs from courting corporate LPs is the value of the networking bond between the VCs and tax-exempt LPs. VCs often have close relationships with the tax-exempt investors in their funds. Tax-exempts are longterm relationship investors likely to make repeat investments with the same $\mathrm{VC}$ professionals over time. VCs like the passive approach that tax-exempts take to their investments, leaving the $\mathrm{VC}$ professionals with broad discretion over the management of the investments in portfolio companies.

Corporate LPs, on the other hand, are meddlesome. As noted above, they are more likely to seek an active role (or at least a monitoring role) with respect to the portfolio companies. There may even be an increased risk that the Corporate LP may appropriate the intellectual property of the portfolio company. Moreover, it is difficult for $\mathrm{VC}$ professionals to develop relationships with corporate managers, even over the ten

\footnotetext{
${ }^{94}$ See Paul A. Gompers \& Josh Lerner, The Determinants of Corporate Venture Capital Success: Organizational Structure, Incentives and Complementarities, NBER Working Paper 6725. Even in successful programs, corporate investors appear to invest at a premium, but as explained by Gompers \& Lerner, the premium might make sense. They explain, "Portfolio companies receiving funds from corporate investors with a well-defined strategic focus enjoy greater success. Investments are made at a premium, but this may reflect the indirect benefits that the corporation receives. Corporate programs with a well-defined strategic focus also appear to be as stable as traditional independent venture organizations. Among the corporate funds without a sound strategic focus, we see significantly less success in the investments and less stability among the focused funds." Id. at 4.
} 
year period of a fund, as turnover rates are much higher at corporations than at taxexempts like CalPers or TIAA-CREF.

Finally, Corporate LPs have a well-earned reputation for being fickle investors who do not always live up to their funding commitments. When a venture fund is formed, the LPs do not contribute cash up front. Rather, each LP makes a commitment to contribute cash when a "capital call" is issued, which occurs over a period of two to four years as the VC Fund identifies worthy investments. Default rates among Corporate LPs are higher than among tax-exempts and this has been especially true in recent years.

In sum, key tax and nontax factors make the tax losses - the central advantage of the Passthrough Structure - worth less than they appear. The lack of attention paid to tax losses is not irrational or based on myth, but rather makes sense in the context of the current tax rules, accounting rules, and institutional investment market.

\section{Gains Are TAXed More Favorably Under the C CORP STRucture}

Tax losses have potential economic value to some corporate LP investors if a Passthrough Structure is used. For the VC professionals and entrepreneurs who negotiate the deal structure, however, gains are taxed more favorably if the C Corp Structure is used. The tax landscape has changed significantly in the last decade, making the treatment of gains more sensitive to the choice of deal structure. In 1992 Congress enacted $\S 1202$, a tax subsidy designed to encourage long-term investment in small businesses, including venture capital startups. ${ }^{95}$ Section 1202 provides for a partial capital gains exemption on the sale of stock in certain small businesses. In 1997, Congress expanded the subsidy further with $\S 1045$, which provides for the rollover of capital gains on the sale of small business stock if the proceeds are reinvested in another small business. This subsidy helps explain why venture capital professionals and other taxable individual investors prefer the C Corp Structure.

\footnotetext{
${ }^{95}$ See Christian Keuschnigg \& Soren Bo Nielsen, Start-Ups, Venture Capitalists, and the Capital Gains Tax (2002) (available on ssrn.com). See David A. Guenther \& Michael Willenborg, 53 J. Fin. Econ. 385 (1999) (finding that $\$ 1202$ reduced cost of capital for small business).
} 


\section{A. The Qualified Small Business Stock Subsidy}

Section 1202 provides a partial exclusion of capital gains for investors in certain small businesses. ${ }^{96}$ The section only applies if the business is organized as a $\mathrm{C}$ Corporation, not a partnership or other passthrough entity. Normally, if an individual investor sells stock in a corporation at a gain, and the stock has been held for more than a year, then the gain on the sale is treated as capital gain and taxed at $20 \%$ rate. $^{97}$ Under $\S$ 1202 , which governs the sale of "qualified small business stock," $50 \%$ of the gains are excluded from the base rate of $28 \%$, effectively creating a $14 \%$ capital gains rate. ${ }^{98}$

A taxpayer must clear several hurdles to qualify for the $\S 1202$ exclusion: among other things, the stock of the qualified small business (QSB) must be held for more than five years, the stock must be acquired from the QSB at original issue, and the gross assets of the QSB must not exceed $\$ 50$ million at the time of issuance. ${ }^{99}$ The exclusion is not available for corporate investors. ${ }^{100}$ The exclusion is, however, important to other taxable investors (i.e. VCs and entrepreneurs), as many portfolio companies financed by VC funds do qualify as QSBs. ${ }^{101}$

Section 1045, which is an extension of $\S 1202$, takes the benefits of QSB status even farther. Under $§ 1045$, taxpayers may roll over the gain otherwise recognized on the sale of QSB stock to the extent the gain is reinvested in a new QSB within six months. ${ }^{102}$ The rollover provision has the effect of pushing down the effective tax rate below $14 \%$,

\footnotetext{
${ }^{96}$ See $\S 1202$.

${ }^{97}$ See $\S \S 1221$ (a) (defining “capital asset”), 1222(3) (defining long-term capital gain), 1(h)(1) (describing rate structure. Before 2003, the usual capital gains rate was $20 \%$ for most long-term holdings, or $18 \%$ for certain property held for five or more years. As discussed below, in 2003, the usual capital gains rate dropped to $15 \%$, making the $\S 1202$ rules less significant.

${ }^{98}$ See $\S 1202$ (c)(1) (restricting definition of qualified small business stock to stock in a C Corporation). ${ }^{99}$ See $\S \S 1202(a)(1)$ (5 year requirement), 1202(c)(1)(B) (original issue requirement); 1202 (d)(1)(B) (\$50,000,000 limitation).

${ }^{100}$ See $\S 1202$ (a)(1) (making 1202 exclusion available "[i]n the case of a taxpayer other than a corporation, ...”).

101 The application of the $\S 1202$ exclusion to limited partners in a venture fund is somewhat complicated, as it is normally the fund and not the limited partner that sells the stock of the QSB. But the tax Code allows the tax break to work to the advantage of the limited partner. The partnership tax rules take an aggregate approach rather than an entity approach, allowing each individual partner of the VC fund to recognize his or her pro rata portion of the capital gain and then apply the 50\% exclusion. See $\S 1202(\mathrm{~g})$.

${ }^{102}$ See $\S 1045(a)$.
} 
theoretically approaching zero if all proceeds are continuously reinvested in new businesses.

This picture has become a bit more complicated with the passage of the Jobs and Growth Tax Relief Reconciliation Act of 2003. The 2003 bill lowered the usual capital gains rate from $20 \%$ to $15 \%$, but section 1202 gain is still calculated from a base rate of $28 \%$, thus closing the differential in rates from $6 \%$ to a slim $1 \%$. Section 1202 thus has more explanatory power for how startups were structure from 1992-2002 than now. The rollover provision of section 1045, however, remains important.

A simple example may help illustrate the mechanics of the exclusion before 2003. Suppose a taxpayer pays $\$ 1$ million for stock of a startup that is a QSB. The taxpayer holds the stock for five years, sells it for $\$ 3$ million and then buys stock of a new qualified startup for $\$ 1$ million. Absent $\S \S 1045$ and 1202, the taxpayer would face a capital gains tax of $20 \%$ times the $\$ 2$ million gain, or $\$ 400,000 .{ }^{103}$ With $\S \S 1045$ and 1202 , the current tax due is $\$ 140,000$, since $\$ 1$ million of gain is rolled over under $\S$ 1045 , and the remaining $\$ 1$ million of gain is taxed at the reduced $\$ 1202$ rate. ${ }^{104}$ Although some of the rollover amount will be recaptured later, when the stock in the new company with a carryover basis is sold, the end result is an effective tax rate somewhere between $7 \%$ and $14 \%$. This rate is significantly lower than the $20 \%$ rate before 2003 , and, in many circumstances, significantly lower than the $15 \%$ rate that currently applies.

\footnotetext{
${ }^{103}$ See $\S \S 1,1221$.

${ }^{104}$ The gain rolled over under $\S 1045$ is deferred, not excluded, as basis in the replacement QSB stock would be zero. See $\S 1045(b)(3)$.

The careful reader will note that the Code does not make it clear if both sections may be used together, and if so, in which order sections 1202 and 1045 apply. In accordance with what appears to be common practice, I apply 1045 first, then 1202, resulting in the lowest possible immediate tax due. Alternatively, one could apply section 1202 alone, resulting in an immediate tax due of $\$ 280,000$, section 1045 alone, resulting in an immediate tax due of $\$ 200,000$, or 1202 first, resulting in a tax due of $\$ 280,000$ and a $\$ 1,000,000$ reduction in the basis of the replacement stock purchased. See Cheryl T. Metrejean et al., Gains on Sales of Qualified Small Business Stock (manuscript on file with author).
} 


\section{SECTION 1202/1045 EXAMPLE}

\begin{tabular}{|l|r|}
\hline Amount Realized & \\
$\quad$ Less 1045 Rollover Amount & $3,000,000$ \\
$=$ Adjusted Amount Realized & $\frac{(1,000,000)}{2,000,000}$ \\
$\quad$ Less Basis & $\frac{(1,000,000)}{1,000,000}$ \\
\hline$=$ Taxable Gain & .14 \\
$\frac{* 14 \%(1202 \text { tax rate })}{=\text { Tax Due }}$ & 140,000 \\
\hline
\end{tabular}

The QSBS subsidy is significant to VCs and entrepreneurs. VCs often require portfolio companies to qualify: QSB status is part of the standard set of representations and warranties found in VC Fund-portfolio company contracts. ${ }^{105}$ While the prevalence of this standard requirement does not prove that the $\S \S 1202 / 1045$ tax break drives the structuring decision, it at least shows that the deal planners (or their lawyers) are aware of the tax incentive. ${ }^{106}$

\section{B. Agency Costs, Continued: Impact of 1202/1045 and NOLs on VC Professionals}

Just as with losses, agency costs help explain the preference for the C Corp Structure regarding gains. The QSBS subsidy does not improve the after-tax returns for most LP investors, since corporate taxable investors are not allowed to take advantage of the subsidy, and tax-exempts and foreign investors do not pay any capital gains tax to begin with. However, the venture capital professionals who manage funds and drive structuring decisions do benefit significantly from the QSBS subsidy, making their effect on the structuring decision stronger than might be expected. Because the QSBS rules

\footnotetext{
${ }^{105}$ See Form of Stock Purchase Agreement, § III (aa) (on file with author) (describing "Section 1202 Compliance").

${ }^{106}$ The C Corp Structure was preferred by deal planners before the $\S \S 1202 / 1045$ subsidies were enacted; the subsidies are probably best viewed as a factor that reinforces the decision to adopt the C Corp Structure rather than a true cause. Indeed, the subsidies may be viewed as an effect rather than as a cause: there is no logical policy reason to limit the subsidies to C Corporations, but the NVCA had a significant role in lobbying for the tax break, and limiting the benefit to C Corporations arguably serves as a good proxy for limiting the benefit to venture capital companies rather than other small businesses. On the lobbying efforts of the NVCA, see, e.g., Steven Lazarus, In the Midst of Tax Cut Debate, QSBS Capital Gains Tax Fix is Within Reach, Venture Capital J., Apr. 1, 2001 (describing NVCA lobbying effort to improve effect of QSBS on taxpayers subject to AMT).
} 
apply only to the sale of corporate stock, not partnership interests, the tax law gives VCs a strong reason to prefer the C Corp Structure.

Also - although this is a counterintuitive point- the C Corp Structure also benefits VCs by trapping tax losses at the entity level. ${ }^{107}$ In the Passthrough Structure, a $\$ 100$ tax loss by the startup generates a $\$ 1$ tax loss for VCs, since VCs are allocated just $1 \%$ of the tax losses. The $\$ 1$ tax loss would be worth, at most, about 40 cents. In the $\mathrm{C}$ Corp Structure, that same $\$ 100$ tax loss creates a $\$ 100$ NOL, which might have a value to the company of $\$ 20$, depending on the company's likelihood and timing of future taxable income (and the application of $\S 382$, as discussed above). When the VC Fund exits the investment, the NOL would increase the valuation of the company by $\$ 20$. This $\$ 20$ increase in valuation might be worth about $\$ 2$ to the VCs, since VCs share in $20 \%$ of the gains allocated to the Fund, and the Fund might be allocated one-half of the increase in valuation, the balance going to the common stockholders. By converting tax losses into an asset which increases valuations, the C Corp Structure makes tax losses about five times more valuable to VCs (albeit less valuable to other investors) - \$2 in the C Corp Structure versus 40 cents in the Passthrough Structure - depending on the discount rate and various restrictions on the company's ability to use the NOL. ${ }^{108}$ In effect, the VCs can expropriate value that would otherwise belong to the LPs, but, to claim this share, the VCs must shrink the size of the overall pie.

The QSBS subsidy has a more substantial effect on the VC's after-tax returns. In the examples in section one, I assumed that capital gains were taxed at a $20 \%$ rate. On that assumption, the predicted value of VC's carried interest is worth, after-tax, $\$ 1.15$ million for GainCorp and \$1.08 million for LossLLC. The C Corp Structure generates a carried interest which, after taxes, is $\$ 70,000$ greater. ${ }^{109}$ If, however, we assume that $\S$

\footnotetext{
${ }^{107}$ I think the point is counterintuitive because it is, at first glance, hard to see how anyone would benefit from trapping losses and thereby hurting the timing value of those losses.

${ }^{108}$ To illustrate the effect of the NOL on the VCs' carry, I return to the GainCorp/LossLLC example from the "Home Run" scenario in section one above. In the example, I assume that GainCorp's NOL, which has a face value of $\$ 9$ million, has a real value of $\$ 3$ million in the eyes of public investors who value the company when it goes public. GainCorp goes public with a valuation of $\$ 303$ million, while LossLLC receives a valuation of $\$ 300$ million. Because of the presence of the NOL, the pre-tax predicted value of the VC's carried interest is slightly higher from the investment in GainCorp versus LossLLC, \$1.44 million versus $\$ 1.35$ million. While this is a difference of only $\$ 90,000$, it is nonetheless significant.

${ }^{109}$ The $\$ 70,000$ increase results from the NOL.
} 
1202 applies, and that capital gains are taxed at 14\%, then the GainCorp carry is worth $\$ 1.24$ million, versus $\$ 1.08$ million for LossLLC. If we further assume that the VCs then raise another fund of, say, $\$ 20$ million dollars, and they commit $\$ 200,000$ of their own capital to the new fund, investing $\$ 100,000$ in new QSB stock within the required time frame, then the $\$ 100,000$ would qualify for rollover under $\S 1045$, and the GainCorp carry is worth $\$ 1.34$ million versus $\$ 1.08$ million for LossLLC. In this case, the VCs' after-tax return on the investment in GainCorp is $\$ 260,000$ greater than the after-tax return on the investment in LossLLC, an increase of nearly $20 \%$.

In sum, because VCs are compensated with a portion of the gains of the entire fund and share in virtually none of the losses, it is entirely rational for them to focus on the tax consequences of potential gains and maximize their own after-tax returns. The effect of NOLs and the QSBS subsidy of $\S 1202$ and 1045 give VCs another rational reason to prefer the C Corp Structure.

\section{COMPlexity AND THE C CoRP Advantage}

It has been easier, historically, to create and run a startup organized as a corporation rather than as a partnership or LLC. Lawyers and deal planners are becoming more adept at addressing the complexities associated with passthrough entities, but some tricky issues remain. It is worth highlighting three areas which illustrate how the corporate form is simpler and easier: employee compensation, corporate governance, and exit strategy. ${ }^{110}$

\footnotetext{
${ }^{110}$ In Silicon Valley Startups, Professor Bankman recognized the complexity of partnerships as a reason commonly cited by deal planners for preferring the C Corp structure, but he seemed to view this as more of a perceived burden than a real one. See Bankman, supra note 3, at 1751-53. Similarly, Professor Bankman did not place much emphasis on the added complexity as it relates to corporate governance or exit strategy. For the reasons discussed below, I think that complexity is a significant friction preventing deal planners from choosing the C Corp structure.
} 


\section{A. Compensating Employees is Simpler}

For an entrepreneur thinking about forming or joining a new business, compensation issues make the C Corp Structure more attractive than the Passthrough Structure. Partnership tax law treats any employee with an equity stake as a partner, complicating compensation issues and increasing tax liabilities for the employees. The chief obstacle relates to the tax treatment of partnership options, although a preliminary discussion of $\S 83$ and the general tax treatment of property granted in exchange for services may be helpful in framing the relevant issues.

Section 83. Section 83 is a timing rule governing what happens when an employee is given property in exchange for services. The baseline rule is that such property is the equivalent of cash salary and is taxable as ordinary income at that point in time at which the property is not subject to substantial risk of forfeiture. ${ }^{111}$ The C Corp Structure allows employees to recognize much of this amount as capital gain through $\S$ 83(b), which allows employees to elect to lock in the ordinary income amount at the initial valuation of the property, ensuring that any future appreciation is treated as capital gain. ${ }^{112}$ In the C Corp Structure, the founders and managers of the startup own the common stock, while the VC Fund takes convertible preferred stock. Because of the liquidation preference attached to the preferred stock, entrepreneurs use a low valuation for the common stock when it is first received and make the $\S 83(\mathrm{~b})$ election, which ensures capital gain treatment on the subsequent sale of the stock. ${ }^{113}$

This result can generally be replicated in the Passthrough Structure with some additional planning. ${ }^{114}$ Instead of stock, the entrepreneur receives a profits interest in the partnership. ${ }^{115}$ When the time comes to incorporate the startup, the entrepreneur exchanges her profits interest in the partnership for common stock in the newly formed

\footnotetext{
${ }^{111}$ See $\S 83$.

${ }^{112}$ See Gilson \& Schizer, supra note 32.

${ }^{113}$ See Gilson \& Schizer, supra note 32.

${ }^{114}$ See Armando Gomez, Selected Issues Relating to Domestic and Foreign Technology Start-Ups and Joint Ventures, 498 PLI/Tax 975, 997 (2001). ("When the venture is organized as a corporation, the issues related to granting equity to employees are easier, but equivalent benefits typically can be granted when the venture is organized as a partnership with some additional planning.")

115 The grant of a profits interest to a service provider may be done without triggering current tax. See Rev. Proc. 93-27, 1993-2 C.B. 343.
} 
corporation. The entrepreneur takes a carryover basis in the stock. Since the entrepreneur had a zero basis in the profits interest, she has a zero basis in the stock. When the stock is subsequently sold, the entrepreneur will pay tax on all the appreciation at a long-term capital gains rate. ${ }^{116}$ Until recently there was some concern whether this strategy worked, but in 2001 the IRS essentially conceded the issue, making it possible to compensate entrepreneurs with partnership equity taxed as capital gain. ${ }^{117}$

QSBS Subsidy for Entrepreneurs. The C Corp Structure does retain one significant advantage over the Passthrough Structure with respect to equity grants, however: the QSBS subsidy. As noted above, under § 1202 the owners of qualified small business stock pay tax on capital gains at a reduced rate of $14 \%$ subject to certain conditions, including a five year holding period. If the Passthrough Structure is used, the LLC would likely be incorporated less than five years before the entrepreneur sells her shares, and the usual $20 \%$ capital gains rate would apply. While this increase from a $14 \%$ to $20 \%$ tax rate is relatively minor compared to the valuation of the deal as a whole, it is enough to give entrepreneurs a reason to prefer the traditional C Corp Structure. The 2003 change in the capital gains rate to $15 \%$ makes section 1202 less important but many entrepreneurs are repeat players, quickly starting a new business as soon as they sell an old one. To the extent proceeds from the sale of one business are reinvested in a new QSB, section 1045 would apply, reducing the effective tax rate below the $15 \%$ that would otherwise apply.

\footnotetext{
${ }^{116}$ Absent a $§ 83(b)$ election, an employee who receives property in exchange for services must normally pay income tax on the appreciation of the property at ordinary income rates. Section 83 principles dictate that the grant of the profits interest goes untaxed, as the profits interest cannot be easily valued at the time of grant. In 2001 the IRS issued a Rev. Proc. stating that employees who receive a profits interest do not need to file a protective $\S 83$ (b) election, provided that certain conditions apply. See Rev. Proc. 2001-43. Therefore, it is possible to compensate entrepreneurs with profits interests in a way that maintains favorable capital gains treatment.

One could even argue that the partnership form is superior, since the favorable treatment under $\S$ 83(b) requires an aggressively low valuation of the common stock at the time of the election, whereas the IRS has conceded that profits interests may be valued at zero under normal circumstances. See Gilson \& Schizer, supra note 32. On the other hand, given the IRS's practice of not challenging valuations of common stock in this context, I question whether the partnership form has any advantages. In any event, I do think that whatever minimal advantage is gained on the valuation question is more than offset by the increased complexity of partnership profits interests.
}

${ }^{117}$ See Rev. Proc. 2001-43. 
Employee/Partner Issues. The C Corp Structure is also advantageous regarding other tax consequences for employees of the startup. In the Passthrough Structure, each employee of the startup who receives an equity stake becomes a partner for tax purposes. Partner status creates several administrative burdens. To start with the mundane, employee/partners would have to be provided with K-1 forms to help them report income at the federal and (perhaps multi-) state level, creating an administrative headache for both employees and for company bookkeepers. As a result of the K-1s, employees would gain access to financial information which top management may not want disclosed. Salary payments to partner/employees can also complicate the administration of capital accounts. ${ }^{118}$ More substantively, employees who are treated as partners would have to pay an additional self-employment tax on salary, would lose full deductibility of health insurance premiums paid on their behalf, and may also suffer negative state income tax consequences. ${ }^{119}$ If the startup does turn a profit, employee/partners will have to report their allocable share of that profit as taxable income, even if the startup has not distributed out cash which the employees can use to pay the tax. ${ }^{120}$ Finally, the Passthrough Structure also complicates both the book and tax treatment of capital accounts as between the partners and the employees, particularly if different partners invest at different times. ${ }^{121}$ Any time a new partnership profits interest is issued, the partnership must "book up" the capital accounts to ensure that entering employees only participate in the subsequent appreciation of asset values. ${ }^{122}$

\footnotetext{
${ }^{118}$ Amounts paid to employees would normally be treated as guaranteed payments to a partner under $\S$ 707(c), but might also be characterized as allocative distributions of partnership income. The Passthrough Structure also creates a risk that the IRS might recharacterize salary payments to non-partner/employees as payments to "disguised" partners, particularly if salary amounts are contingent on the performance of the company.

${ }^{119}$ See $\S 1401$ et seq. The self-employment tax is the equivalent of a payroll tax on corporate employees; to make matters worse, however, LLC members must pay tax of $15.3 \%$ of their total distributive share, including profits as well as guaranteed payments (i.e. salary), subject to the usual cap on social security contributions. Corporate employees, on the other hand, only pay tax on salary, not other distributions. LLC members receive a $60 \%$ deduction for health insurance premiums, while corporations receive a $100 \%$ deduction.

${ }^{120}$ See $\S 704$.

${ }^{121}$ See New York State Bar Association Tax Section Report on the Taxation of Partnership Options and Convertible Securities, 2002 TNT 21-24, at pin (2002) (hereinafter NYSBA Report).

${ }^{122}$ Tax lawyers have begun to tinker with the Passthrough Structure to ameliorate the employee/partner problem. For example, a startup might create a special subsidiary to act as a management company. The founders and managers would still receive profits interests, making them partners in the partnership. But
} 
Partnership Options. The C Corp Structure is superior with respect to another compensation issue: options. A venture capital startup using the C Corp Structure typically creates an option pool to entice talented employees and reduce the amount of cash compensation necessary to hire competitively. It is generally assumed that partnership options are taxed much the same as stock options, but there is little authority and much uncertainty surrounding this area. ${ }^{123}$

The granting of a partnership option is relatively unproblematic, as it is accepted that the grant of the option is not a taxable event to either the entrepreneur or the partnership, unless the option has a "readily ascertainable fair market value" when granted, which will not normally be the case. ${ }^{124}$ It is possible, however, that merely granting a partnership option makes the holder a partner for tax purposes, leading to the administrative nuisances described above. ${ }^{125}$

There are additional complications when the employee exercises the option. If the option gives the holder the right to acquire a profits interest, it unclear what amount, if any, is taxable at exercise. ${ }^{126}$ If the option gives the holder the right to acquire a capital interest, then it is clear that some amount should be taxable at exercise, but it is unclear how this amount should be measured. ${ }^{127}$ Moreover, assuming some amount is taxable to the holder, then the partnership should receive a deduction, but it is unclear how the

instead of being employed by the partnership directly, the partnership would create a C Corporation to act as a management company, and the founders and managers would become employees of the management company, receiving salary and benefits just like other employees. The management company would be reimbursed for salary payments on a cost-plus basis. While this solution solves some of the employee/partner problems, it is not a silver bullet; every layer of organization adds to the filing fees and legal and accounting overhead of the business, and the C Corp Structure is still easier to understand and implement.

${ }^{123}$ See IRS Notice 2000-29, 2000-23 I.R.B. 1241 (requesting public comment on treatment of partnership options); NYSBA Report, supra note 115, at text accompanying note 3.

${ }^{124}$ See Treas. Reg § 1.83-7.

${ }^{125}$ See NYSBA Report, supra note 115, at 1181.

${ }^{126}$ See NYSBA Report, supra note 115 , at 1201 . Under general $\S 83$ principles, the holder should be taxed on the difference between the true fair market value and the amount of the exercise price plus any option premium paid. Under Subchapter K principles, however, a liquidation analysis would be used, normally resulting in zero value for a profits interest and a lower value for a capital interest.

${ }^{127}$ A liquidation analysis would likely result in a low valuation if the VC Fund retains rights to get allocations first that reflect a liquidation preference. 
deduction may be allocated among the various existing and incoming partners. ${ }^{128}$ It is also unclear whether the exercise is a taxable event to the historic partners as a deemed sale of a portion of partnership assets to the incoming partner. ${ }^{129}$ As the assets of the startup will have appreciated in value at the time of the exercise, the historic partners risk accelerating a tax bill at a time when they are unlikely to have cash with which to pay the tax. Finally, it is also worth noting that partnership options make it more difficult to maintain proper capital accounts. ${ }^{130}$

Partnership options may also have "bad" accounting treatment, meaning that it may be necessary for companies to treat partnership options as a current expense on the income statement, thereby depressing reported earnings. Most companies today do not treat stock options as a current expense of the company, taking no charge against earnings when stock options are granted. The current accounting rules, found in Accounting Principles Board Opinion No. 25 (APB 25) and Financial Accounting Standards Board No. 123 (FASB 123) address stock-based equity interests. The treatment of partnership options, however, is not specified. ${ }^{131}$ The National Venture Capital Association and other lobbying groups have been fighting hard to protect the existing accounting treatment of stock options, which many observers and legislators feel is unjustified. ${ }^{132}$ The ultimate outcome of that legislative battle is unknown. In the meantime, venture capital professionals are unlikely to want to open up a new battlefront over the accounting treatment of partnership options.

Finally, the complexity of drafting partnership options cannot be dismissed. Although the theory is relatively simple for those familiar with partnership tax principles,

\footnotetext{
${ }^{128}$ To avoid negative tax consequences to the incoming partner, some partnerships will make a special allocation of the entire partnership deduction to the incoming partner, thereby completely offsetting the incoming partner's tax liability. It is questionable whether this strategy conforms with the $\S 704(\mathrm{~b})$ regulations.

${ }^{129}$ See NYSBA Report, supra note 115 , at text accompanying note 4.

${ }^{130}$ See NYSBA Report, supra note 115, at 1206.

${ }^{131}$ See Joseph E. Bachelder, Equity Participation by Executives in Main Street/Dot Com Ventures, 1213 PLI / Corp 67, 73 (2000) (stating that FASB 123 applies to options to acquire capital interests, but that treatment of options to acquire profits interests is unclear). Arguably, the same standards apply to options to acquire capital interests in a partnership or even profits interests in the partnership. But given that FASB 123 is under attack in the wake of the Enron scandal, accountants may not be as willing to be aggressive.

${ }^{132}$ See http://www.nvca.com (describing Senate testimony of NVCA president) (site last visited August $28,2002)$.
} 
the mechanics are difficult. In particular, the flexibility and variability of partnership agreements with regard to the allocation of income and loss and the maintenance of capital accounts makes the drafting extremely tricky. As one practitioner has explained,

Drafting an option on a partnership interest is a complex task and is normally much more difficult than drafting an option on a share of common stock in the corporate context. It requires an understanding of the parties' economic deal, the partnership's allocation, distribution and capital account mechanics and the interaction of those mechanics with the purchase of a partnership interest on exercise of the option (including, e.g., the initial capital account to be given to [the service partner] on exercise of the option and the impact of writing up (or not writing up) capital accounts on option exercise). ${ }^{133}$

This complexity not only increases legal costs, it could make it more difficult to attract talented employees. Unlike executives of public companies, startup employees often do not retain counsel, instead relying on the company to explain the employment compensation package. Employees may be suspicious of the more complicated nature of partnership options and discount the value of the proposed compensation package accordingly.

\section{B. Corporate Governance and Drafting}

Corporate law differences between a closely-held corporation and a limited liability company are generally thought to be insignificant. ${ }^{134}$ In practice, however, there is enough uncertainty about how corporate governance provisions will be applied, and there are enough difficult drafting issues, so that even today clients are sometimes wary about using a non-corporate entity. LLCs are somewhat new: although the first LLC statute was passed in 1977, they did not become commonplace until the 1990s. ${ }^{135}$ As a

\footnotetext{
${ }^{133}$ William R. Welke \& Olga A. Loy, Compensating the Service Partner with Partnership Equity: Code $\S 83$ and Other Issues, 493 PLI/Tax 625, 683-84.

${ }^{134}$ See Bankman, Silicon Valley Startups, supra note 3, at 1749.

${ }^{135}$ Before 1996, private companies had to pass a cumbersome four-factor test to qualify as partnerships for tax purposes. Although tax lawyers became quite adept at drafting the necessary language, it was not until the Check-the-Box regulations were issued that partnership tax treatment became a simple matter of literally checking a box on an IRS form. See Victor Fleischer, If it Looks Like a Duck: Corporate Resemblance and Check-the-Box Elective Tax Classification, 96 Colum. L. Rev. 518, 519 (describing elective features of Check-the-Box).
} 
result, there is little case law outlining the rights and obligations of LLC members. ${ }^{136}$ In general, LLCs offer flexibility with respect to management of the company, the rights and obligations from one member to another, and disclosure obligations. Some states, including Delaware, even permit members to waive fiduciary duties. ${ }^{137}$ Flexibility brings uncertainty, both in terms of determining what rights LLC agreements confer and whether the agreements will be enforceable in court.

Uncertainty creates a significant information cost. When a startup is organized as a corporation, it is easy for the parties to understand and value their rights and obligations. For example, when the VC Fund in the C Corp Structure receives preferred stock, it is understood, without even looking at the charter, that no dividend may be paid to the common stockholders so long as the preferred's dividend is outstanding, and if the startup is liquidated, the VC Fund will receive all of the proceeds until its liquidation preference is satisfied. ${ }^{138}$ Under the Passthrough Structure, on the other hand, there are no such limitations on distributions until the parties agree to them in the LLC operating agreement. A "capital interest" in an LLC has no meaning other than what the parties assign to it. ${ }^{139}$ Another example is fiduciary duty: under the C Corp Structure venture capital fund managers who sit on the board of the startup have a fiduciary duty of care and duty of loyalty to the startup's founders and managers. ${ }^{140}$ If an LLC is used, it is unclear what duties, if any, the VCs owe to the founders and managers; a VC director may be free to divert corporate opportunities away from the LLC startup to other portfolio companies. To ensure that the founders and managers of the startup are protected, the startup's lawyers have to draft appropriate protections in the LLC operating

\footnotetext{
${ }^{136}$ See David L. Cohen, Theories of the Corporation and the Limited Liability Company: How Should Courts and Legislatures Articulate Rules for Piercing the Corporate Veil, Fiduciary Responsibility and Securities Regulation for the Limited Liability Company, 51 Okla. L Rev. 427, 454-68 (1998).

${ }^{137}$ See Wayne N. Gazur, The Limited Liability Company Experiment: Unlimited Flexibility, Uncertain Role, 58 Law \& Contemp. Probs. 135, 174 (1995).

${ }^{138}$ See Del. Gen. Corp. Law $\S 170$.

${ }^{139}$ See Del. LLC Act $\S \S 18-504,18-804$.

${ }^{140}$ See, e.g., Jonathan R. Macey, Smith v. Van Gorkam: Insights about C.E.O.s, Corporate Law Rules, and the Jurisdictional Competition for Corporate Charters, 96 Northwestern L. Rev. 607 (2002).
} 
agreement. Other commentators have noted that the lack of well-established practices and default rules for LLCs increases transaction costs in the venture capital context. ${ }^{141}$

Granted, these differences in corporate governance are relatively minor and can be addressed in the drafting process. Moreover, parties might be more concerned with their reputation than with their legal rights and obligations. ${ }^{142}$ Indeed, in recent years, outside the context of VC-managed funds, deal planners have developed a hybrid structure that uses both an LLC and a corporation. ${ }^{143}$ Nevertheless, the uncertainty of the LLC form increases legal costs and is an unwelcome addition to a negotiating atmosphere already laden with uncertainty and distrust. In particular, entrepreneurs who are accustomed to running corporations might resist trying out a new and unfamiliar entity. For startups that hope to incorporate within a few years anyway, adding an extra layer of legal costs, complexity, and uncertainty is unappealing, creating another reason why entrepreneurs and venture capital professionals prefer the C Corp Structure.

\footnotetext{
${ }^{141}$ Professor Deborah DeMott has observed that LLCs do not normally differentiate between managing and monitoring, the latter being the VCs' typical role in the C Corp Structure. See Deborah A. DeMott, Agency and the Unincorporated Firm: Reflections on Design on the Same Plane of Interest, 54 Wash. \& Lee L. Rev. 595, 608 (discussing Bankman's puzzle and noting that "[c]onsiderable ingenuity could be expended on attempts to replicate the governance structure created by corporate law in an unincorporated firm in order to place the venture capitalist in an authoritative and informed position to monitor management and to intervene when warranted without itself undertaking the burdens - and liabilities - of direct operational management. A differentiated monitoring function is not an expressly stated option for the structures created under partnership statutes and under most LLC statutes.") See also Callison, supra note 15 .

${ }^{142}$ See generally D. Gordon Smith, Venture Capital Contracting in the Information Age, 2 J. Small \& Emerging Bus. L. 133, 156-170 (1998) (describing role of reputation in venture capital industry).

${ }^{143}$ The emergence of the hybrid structure suggests that path dependence is not a very strong explanation for current behavior. As Professor Bankman explained, there is a collective action problem in that the switching costs might outweigh the benefits for any particular firm. See Bankman, Silicon Valley Startups, supra note 3, at 1768. See also Marcel Kahan \& Michael Klausner, Standardization and Innovation in Corporate Contracting (or, "The Economics of Boilerplate"), 83 Va. L. Rev. 713 (1997).
}

In recent years, however, corporate investors have used a hybrid structure called, not very creatively, the "Barnes and Noble dot com Structure." In the B\&N.com structure, a corporate parent (or two) creates a special purpose subsidiary that becomes the managing member of an LLC. Another corporation is created as an IPO vehicle and becomes the other member of the LLC. Through a high-vote / low-vote structure, the corporate investor can maintain control over the startup and enjoy the passthrough of tax losses; the IPO vehicle facilitates exit strategy. The development of the hybrid structure shows that where the tax losses are truly valuable - i.e., when most of the money invested in the startup comes from a corporate taxable investor - deal planners can overcome the path dependence problem and use a different structure. 


\section{Smoother Exit Strategy}

Corporate governance and employee compensation issues make the C Corp Structure advantageous for creating and running a startup. It is also vital to examine exit strategy, where - in most cases - it is also easier for investors to sell their stake in a venture capital startup if it has been structured as a corporation from the beginning. ${ }^{144}$

Of course, partnerships and LLCs may legally convert into corporations, and often do. The incorporation process is not as easy as it might seem, however, particularly when a sale or reorganization is close at hand. ${ }^{145}$ Professor Bankman notes that the transition from partnership to corporation is expensive, costing perhaps $\$ 200,000$ in additional legal fees. ${ }^{146}$ Bankman correctly argues, however, that the transaction costs cannot fully explain the structuring choice, as the conversion costs amount to only a small percentage of the value of the tax deductions lost. ${ }^{147}$

${ }^{144}$ See D. Gordon Smith, Control over Exit in Venture Capital Relationships 5 (2001) (available on ssrn.com); Manuel A. Utset, Reciprocal Fairness, Strategic Behavior and Venture Survival: A Theory of Venture Capital-Financed Firms, 2002 Wisc. L. Rev. 45, 68 (describing VC control over exit).

It is tempting to tell a signaling story here. In a 1997 symposium, Professor Ian Ayres raised signaling as a possible explanation for the choice of organizational structure. See Ian Ayres, Never Confuse Efficiency with a Liver Complaint, 1997 Wisc. L. Rev. 503, 517 (discussing importance of sociological explanations for irrational economic behavior and raising possibility that "Bankman does not adequately consider how the choice to incorporate might be a way for managers to signal to venture capitalists a higher likelihood that the firm will succeed.") [ ]. Organizing as a corporation focuses attention on gains, not losses. Exit strategy might be an especially important area to signal, as organizing as a corporation could signal that an IPO or acquisition is the preferred exit. In other words - to continue the baseball metaphor - organizing as a corporation sends a positive signal, like Babe Ruth's pointing his bat at the right field bleachers. Organizing as a partnership, on the other hand, would send a negative signal, like squaring around to lay down a bunt.

The signaling story works, however, only if the signal (the choice of organizational form) is expensive to send, so that only high quality firms can send the signal. Here, both good and bad firms send the signal, creating a pooling equilibrium rather than a separating equilibrium. See Douglas G. Baird et al., Game Theory and the Law 83 (1994). Thus, there may be some stigma associated with choosing the partnership form (as it shows possible disregard for the importance of keeping organizational expenses low), but the existence of the hybrid structure, supra note --, suggests that whatever negative signal is sent is easy to overcome.

${ }^{145}$ But cf. John M. Cunningham, The Limited Liability Company: Entity of Choice for High-Tech StartUps?, 13 Computer Law. 11, 17 (1996) (recommending LLC if likely exit is asset sale, C Corp if likely exit is stock sale, arguing that IPO exit is irrelevant because incorporation process is "manageable").

${ }^{146}$ See Bankman, Silicon Valley Startups, supra note 3, at 1750.

${ }^{147}$ See Bankman, Silicon Valley Startups, supra note 3, at 1750. 
But neither should one dismiss the complexity of conversion right before exit. A successful exit is always possible, but exiting is simpler and cheaper if the startup has been organized as a corporation from the outset. Incorporating a business just before selling or going public can cause unwanted delays. It requires management to face further complicating an already cumbersome process at the most sensitive time for a startup - when it has finally turned the corner and may be sold to a third party or shopped to investment bankers for a potential IPO. Specifically, incorporation introduces an opportunity for holdup, as each manager will be asked to exchange her partnership interest (or option) for stock or options in the new entity. Because the enthusiastic participation of management is essential to a successful road show, managers may be in a position to extract additional value from the company at this sensitive time. This could happen, even if management continues to hold shares in the same company. But by forcing management into an exchange, incorporation encourages managers to engage their attorneys and renegotiate their own personal deals with the company.

Complicating the IPO Process. Initial public offerings hold a sanctified status in the world of startups. ${ }^{148}$ The IPO market has cooled off in recent years. Successful startups are now more likely to be acquired by a trade buyer than to go public. ${ }^{149}$ But the

${ }^{148}$ IPOs even attained status in pop culture, generating buzz in Silicon Valley in California, "Silicon Alley" in New York, and other high-tech corridors in Austin, Route 128 outside Boston, Northern Virginia, and Atlanta. See, e.g., [cite to newspaper articles]. Going public became an end in and of itself for many startups that pushed perhaps too rapidly during the tech bubble of 1998-200. See Dот Con (describing rapid growth of Kozmo.com); STARTUP.COM (describing rapid growth of govWorks.com).

When venture capital funds list their successful investments, they highlight companies that have gone public and become a household name. See, e.g., Kleiner Perkins website (http://www.kpcb.com/) (listing AOL, Amazon, Sun, Genentech, Compaq, Juniper); Accel Partners website (http://www.accel.com/home.asp) (listing Real Networks, Veritas, UUNet, Foundry, AMCC, Agile Software, and Macromedia). The frequency with which a venture capital fund's portfolio companies go public is a central measure of the VC's reputation in the eyes of LP investors. See Bernard S. Black \& Ronald J. Gilson, Venture Capital and the Structure of Capital Markets: Banks versus Stock Markets , 47 J. Fin. Econ pin (1997). Taking a company public can benefit a VC's reputation to such an extent that some VCs (especially at less established VC firms) are willing to sacrifice value in order to complete a public offering and thereby improve their name-recognition, even at the expense of other stakeholders. See Paul A. Gompers, Grandstanding in the Venture Capital Industry, 42 J. Fin. Econ. 133 (1996).

Indeed, the lure of the IPO is sometimes stronger than it should be; VCs tend to take companies public prematurely when the fund nears the end of its ten-year life. See Gompers \& Lerner, Venture Capital Cycle, supra note 32 , ch. 12. Gompers \& Lerner also find that younger less-established VC firms take companies public sooner than well-established VC firms, and that IPO underpricing is more likely to occur. Id. See also Michael Klausner \& Kate Litvak, What Economists Have Taught Us About Venture Capital Contracting, at 13 (2001) (working paper, available on ssrn.com).

${ }^{149}$ See supra note 45 . 
availability of a public stock market is critical to the existence of a venture capital industry. ${ }^{150}$ Public offerings provide liquidity for venture capital investors at often generous valuations. Moreover, the availability of an IPO exit allows VCs to enter into an implicit contract with entrepreneurs concerning the future control of the startup: control which is carefully allocated between the VCs and the entrepreneurs passes back to the entrepreneur when the VCs exit. ${ }^{151}$ In effect, IPO potential gives entrepreneurs a call option on control exercisable in the event of great success.

Deal structures that potentially complicate the IPO process are frowned upon. ${ }^{152}$ At first glance it would appear to be quite easy to incorporate quickly in advance of a possible IPO. The corporate filings are cheap and basically simple. The mechanics of the process can make conversion tricky, however, since different methods produce different tax consequences. ${ }^{153}$

\footnotetext{
${ }^{150}$ See Black \& Gilson, supra note 140, at pin ("We argue that a well developed stock market that permits venture capitalists to exit through an initial public offering (IPO) is critical to the existence of a vibrant venture capital market.”). See also Douglas Cumming \& Jeffrey G. MacIntosh, The Extent of Venture Capital Exits: Evidence from Canada and the United States (2002) (available on ssrn.com); Armin Schweinbacher, An Analysis of Venture Capital Exits in Europe and the United States (2002) (available on ssrn.com).

${ }^{151}$ Black \& Gilson, supra note 140, at 22. See also Bratton, supra note 32, at pin (describing importance of shared control mechanism).

${ }^{152}$ See Michael R. Darby \& Lynn G. Zucker, Going Public When You Can in Biotechnology (2002) (Working Paper on file with author) (noting desire of biotech firms to go public when IPO market is open, not just when science base is sufficient).

153 There are three options for incorporating a partnership or LLC, each of which attains the same goal of creating a corporate entity that can sell shares to the public in an IPO. See generally Rev. Rul. 84-111 (recognizing different tax consequences depending on method used). The first option is to have the partnership contribute the assets to a newly formed corporation (Newco) in exchange for 100\% of Newco's common stock. Newco then sells newly-issued shares of common stock to the public, thereby splitting the ownership between the partnership and the public. Sometime after the IPO the partnership would liquidate, distributing the Newco stock upstream to the VC Fund and the managers and founders of the startup. The VC Fund could then sell shares to the public in a secondary offering or distribute the shares to the LP investors.
}

The second option is to have the VC fund and the startup's management contribute their partnership interests to Newco in exchange for common stock. The Newco stock would be allocated between the Fund and management according to the original partnership agreement. Newco would then own $100 \%$ of the partnership. The partnership would automatically be liquidated, and Newco would then own the assets of the partnership directly. Newco would then sell shares to the public in an IPO, and the Fund, now holding marketable shares, could follow suit in a secondary offering.

The third option begins with a momentary liquidation of the business. The partnership would liquidate, distributing its assets upstream to the VC fund and the startup's management as outlined in the partnership agreement. The VC fund and management would then immediately contribute those assets to 
Incorporating before an IPO can also create a securities law issue for LP investors, particularly if the startup was not meticulously advised by legal counsel when it was first organized. Under Rule 144, the SEC requires selling shareholders in a private company to hold securities for at least one year prior to sale. The holding period of LLC or partnership interests normally does not tack to the corporate stock received in the exchange. This holding period rule potentially delays the exit of the VC Fund by up to one year - six months or nine months longer than underwriters normally require.

Sophisticated lawyers may be able to structure around this SEC Rule: commentators have noted that if the original LLC operating agreement provides that the entity will incorporate in connection with an IPO, that no additional consideration will be paid by investors in connection with the incorporation, and that the incorporation will cause no shift in the holders' economic interests not contemplated by the original documents, then the Rule 144 restriction should not apply. ${ }^{154}$ So long as the entire IPO process - from the exchange of partnership interests for convertible preferred stock followed by conversion to common followed by sale to the public - was contemplated and outlined in the original documents, the SEC rule should not prove to be too high a hurdle for selling shareholders. It does, however, require some additional planning, adding yet again to the transaction costs of the Passthrough Structure.

Incorporating on the eve of an IPO can also create tax problems if the VC Fund or other shareholders plan to sell a significant stake of the business to the public in the IPO, although underwriters usually prevent such sales from happening. From a tax

Newco in exchange for common stock. Newco could then sell shares to the public in an IPO, and the Fund could follow with a secondary offering.

Valuation problems probably make option one the most attractive. The VC Fund typically holds a large liquidation preference which drops away upon completion of a "qualified IPO." The liquidation preference gives the startup's founders and managers a strong incentive to build the business rapidly and successfully. Under options two and three, however, even if an IPO were in sight, the partnership would be liquidated before the completion of the qualified IPO, and the founders and managers would effectively be punished instead of rewarded. The first option - liquidating the partnership after the IPO - solves the valuation problem by leaving the liquidation preference in place until after the IPO. The partnership remains intact as the majority shareholder of Newco. One possible drawback is an information cost problem for IPO investors: IPO investors might be concerned that $75 \%$ of the shares of Newco would continue to be held by a single entity (the partnership), and presumably would want to understand how the partnership's internal governance works.

${ }^{154}$ See Jack S. Levin, Structuring Venture Capital, Private Equity, and Entrepreneurial Transactions $\S$ 903.4 (1998). 
perspective, the concern is the control requirement of $\S 351 .{ }^{155}$ Setion 351 allows shareholders to contribute property to a corporation which they control in exchange for stock without realizing any gain on the appreciation in the value of the property. ${ }^{156}$ For an exchange to qualify as a good $\S 351$ transaction, the contributors of the property must remain in control of the new corporation immediately after the exchange. ${ }^{157}$ The issue is what is meant by the language "immediately after." A literal interpretation of the Code suggests that there is no problem, as the incorporation would take place at least a few days before the IPO. Under the step-transaction doctrine, however, the IRS or the courts may determine the tax consequences of a transaction completed through a series of integrated steps by looking at the steps taken together, not by evaluating each step separately. Case law in this area is generally taxpayer-favorable, indicating that absent a "binding commitment" to sell shares at the time of incorporation, then incorporation will be viewed as an independent $\S 351$ transaction. ${ }^{158}$ By the time selling shareholders have a binding commitment, the incorporation will be "old and cold."

${ }^{155}$ See generally Jeffrey T. Sheffield \& Christian E. Kimball, Organizing the Corporate Venture, 465 PLI Tax 287 § 5 (2000) (describing case law and rulings pertaining to control "immediately after" the exchange); Ronald H. Jensen, Of Form and Substance: Tax-Free Incorporations and other Transactions under Section 351, 11 Va. Tax Rev. 349 (1991) (arguing for flexible interpretation of 80\% control requirement and limited application of step transaction doctrine).

${ }^{156}$ Upon incorporation, the partnership would contribute property to Newco in exchange for $100 \%$ of the common stock. The property contributed would be the assets of the business: intellectual property, equipment, goodwill, and so on. These assets are likely to have a low basis and a high fair market value, creating a high potential tax bill. If the contribution qualifies under $\S 351$, however, no current tax will be owed, and the partnership would take a substitute basis in Newco stock equal to its basis in the contributed assets. See $\S 358$ (a). If the contribution does not qualify under $\S 351$, then the partnership would recognize income equal to the fair market value over the basis of the assets, and the income would be allocated between the Fund and management according to the partnership agreement. See $\S 1001$ (sale or exchange). If the 351 transaction is not treated as a nonrecognition event, then the consequences are quite punitive. The partnership's contribution of assets to the corporation would be a taxable exchange, and the partners would have to recognize gain to the extent that the fair market value of the stock received in the exchange exceeds the partnership's (low) inside basis in the assets.

${ }^{157}$ See $\S 351$ (a). "Control” in this context is defined by $\S 368(\mathrm{c})$, which defines control as "ownership of stock possessing at least 80 percent of the total combined voting power of all classes of stock entitled to vote and at least 80 percent of the total number of shares of all other classes of stock of the corporation." See $\S 368(c)$.

${ }^{158}$ The three usual formulations of the step transaction doctrine are the "end result" test, the "mutual interdependence" test, and the "binding commitment" test. See generally McDonald's Restaurants of Ill., Inc. v. Commissioner, 688 F.2d 520, 524-25 (7th Cir. 1982) (discussing formulations). Most courts have found the binding commitment test to be overly narrow. See, e.g., Boris I. Bittker \& James S. Eustice, Federal Income Taxation of Corporations and Shareholders II 12.61[3], at 12-210 (6th ed. 1997) (noting that binding commitment test "may be reserved for situations where the taxpayer, rather than the government, is seeking to invoke the [step transaction] doctrine"). 
An issue arises, however, when public investors buy preexisting shares of Newco from the VC Fund in the initial public offering or in a secondary offering. Because the public investors do not contribute cash or property to Newco, it cannot be argued that they form part of the control group. If at the time of incorporation there is a binding commitment to sell between a transferor and a third party who is not part of the original control group, then the transaction will not qualify under $\S 351 .^{159}$ Where there is an intention to sell but no binding commitment, the law is less clear. ${ }^{160}$ Normally, underwriters will require insiders to agree to a lockup provision, requiring them to hold on to their shares for 3 months or longer following the IPO. Given this lockup

For primary offerings of shares by the company to the public, the step transaction doctrine is not an issue, as the partnership may count the public investors as part of the $80 \%$ control group required by $\S$ 351. A Treasury regulation provides that in the case of a "qualified underwriting transaction" persons who acquire stock from an underwriter are treated as if they acquired stock directly from the company, regardless of whether the underwriting takes place on a best efforts basis (where the underwriter merely acts as an agent for the corporation) or a firm commitment basis (where the underwriter buys the stock from the company and immediately resells to the public). See Treas. Reg. § 1.351-1(a)(3). This works if the investors are buying newly-issued shares, as they would be contributing property in exchange for Newco stock.

Complicating the issue somewhat is the shift of ownership which often follows soon after an IPO. The shift of significant control over non-operational matters from the insiders (the startup's founders and management and the $\mathrm{VC}$ fund) to the public is the a principal purpose for the incorporation and the change in organizational structure; to say that the incorporation is a truly separate transaction from the IPO and secondary offerings which follow elevates form over substance in a way that may be inconsistent with the way the step transaction doctrine is generally applied. See Jensen, Of Form and Substance: Tax-Free Incorporations and Other Transactions Under Section 351, 11 Va. Tax Rev. 341 (1991) (noting that binding commitment formulation seems to apply only in the case of 351 transactions and D reorgs). As explained in a leading treatise, "where the loss of control, although not pursuant to a binding obligation, is both part of a preconceived plan and a sine qua non thereof," then the step transaction doctrine should apply, even in the context of $\S 351$. See Bittker \& Eustice at para. 3.09[2] ( $7^{\text {th }}$ ed. 2002). But see American Bantam Car Co. v. Commissioner, 11 T.C. 397 (1948), aff'd per curiam 177 F.2d 513 (3d Cir. 1949) (holding that three days delay between incorporation and IPO is sufficient to preclude step transaction doctrine); $\underline{\text { Scientific }}$ Instrument Co. v. Commissioner, 17 T.C. 1253 (1952), aff'd per curiam, 202 F.2d 155 (6 ${ }^{\text {th }}$ Cir. 1953) (holding that step transaction doctrine did not apply where sale to the public was intended but was not consummated until six months following incorporation).

${ }^{159}$ May Broadcasting Co., 200 F.2d 852 (8 ${ }^{\text {th }}$ Cir. 1953); see also Intermountain Lumber Co. v. Commissioner, 65 T.C. 1025 (1978); Manhattan Bldg. Co. v. Commissioner, 27 T.C. 1032 (1957); Hazeltine Corp. v. Commissioner, 89 F.2d 513 (3d Cir. 1937).

${ }^{160}$ The Ninth Circuit has suggested in dicta that even absent a binding commitment, a plan to incorporate and then dispose of control is enough to run afoul of section 351, regardless of whether the parties were legally bound to complete the sale. Culligan Water Conditioning v. United States, 567 F.2d $867\left(9^{\text {th }}\right.$ Cir. 1978). And in other contexts, the step transaction doctrine is applied to integrate steps of a transaction based on the "mutual interdependence" of the steps or the "end result," either of which would suggest that section 351 should not apply. 
requirement, most tax lawyers are comfortable giving an opinion that the step transaction doctrine will not apply. ${ }^{161}$ Nevertheless, some uncertainty remains.

Incorporating just prior to an IPO also creates an extra opportunity for conflict between the startup's founders and managers and the VC Fund. The parties will likely want to draft new agreements outlining their rights with respect to the IPO or other potential exits, especially if these agreements were not comprehensively drafted at the outset. The VC Fund may ask for a registration rights agreement. ${ }^{162}$ Drag-along and tagalong rights in the original partnership agreement might also have to be revised to reflect the new situation. Planning for these issues in advance can minimize costly and timeconsuming negotiations. However, since most startups are not willing to pay counsel more than a bare minimum for legal costs at the time when the startup is first organized, it is unrealistic to expect sophisticated planning to take place until much later in the life of the venture.

Incorporating on the eve of an IPO therefore raises a few issues that do not exist where the startup was organized as a corporation from the beginning. Although corporate and tax lawyers are becoming more skilled at planning for incorporation, the extra step of conversion adds some cost and complexity to the process.

Tax-free Sale to a Trade Buyer. For a C Corporation, merger with or acquisition by a third party is relatively painless and affords potential acquirors a fair degree of flexibility. Although the transaction may take different forms, each of which has different requirements, most of the time the buyer can acquire the stock of the target $\mathrm{C}$ Corporation tax-free in exchange for stock of the buyer or a combination of stock and cash. $^{163}$

Partnerships cannot take advantage of the usual reorganization provisions of $\S$ 368. Nor can they incorporate just before being acquired: the control requirement of $\S$

\footnotetext{
${ }^{161}$ There is a strong argument, given the other case law, that the Ninth Circuit dicta is wrong, and that absent a binding commitment to sell to the public in a secondary offering, the step transaction doctrine should not apply. After all, a significant number of companies do poorly after an IPO, and the fund may be left holding shares that it cannot sell. Similarly, management may want to dispose of shares after the IPO lockup expires, but its ability to do so absent a binding commitment is subject to the whims of the marketplace. See O’Connor v. Commissioner, 16 T.C.M. 213 (1957).

${ }^{162}$ It would be difficult although presumably not impossible to have drafted a registration rights agreement in advance concerning the registration of securities that do not yet exist.

${ }^{163}$ See $\S 368$.
} 
351 is a significant barrier (and not just an aggravation) when a trade buyer seeks to acquire a partnership in a tax-free reorganization under $\S 368$. Unlike in the IPO context, where case law and IRS rulings are generous to the taxpayer, in the reorganization context common law tax doctrines preclude a tax-free incorporation immediately before the merger. ${ }^{164}$

It may be possible for certain trade buyers to acquire a partnership in a tax-free transaction. For example, in a $\S 351$ acquisition structure, the buyer's shareholders would contribute all of their stock in the buyer to Newco in exchange for Newco common stock, and the sellers would contribute their partnership interests to Newco in exchange for Newco common stock. Although tax-free, the structure has a notable weakness: larger trade buyers whose stock is publicly traded are not likely to want to undergo a major change in capital structure in order to acquire a small startup. One cannot imagine Cisco, for example, asking all its shareholders to exchange their stock every time a new startup is acquired. Thus, the structure really only makes sense for a merger of equals, which, while not unusual, is not usually the most profitable exit strategy. ${ }^{165}$

Taxable Sale to a Trade Buyer. For taxable deals, the Passthrough Structure is somewhat more complex than the C Corp Structure but might actually be advantageous. Using the Passthrough Structure ensures the advantage of incurring only one level of tax. If the partners exit by selling their partnership interests to the buyer for cash, they will

\footnotetext{
${ }^{164}$ See Jack S. Levin, Structuring Venture Capital, Private Equity, and Entrepreneurial Transactions $§$ 302.10 (1998). To take advantage of the traditional tax-free reorganization provisions of $\S 368$, the partnership would first have to incorporate prior to the acquisition, raising a step transaction issue under $\S$ 351. In Revenue Ruling 70-140, a taxpayer transferred assets to a wholly owned corporation in a putative $\S$ 351 transaction, followed by a transfer of the newly issued stock of the corporation to a buyer in a B reorganization. The IRS ruled that the taxpayer did not satisfy the control requirement of $\S 351$. Because the $\S 351$ and the B reorganization occurred as part of a prearranged plan, the use of the corporate form was transitory and without substance, the transfer did not qualify under $\S 351$, and the taxpayer had to pay tax on the incorporation as if it were a taxable sale of the assets. The taxpayer fared better in Weikel v. Commissioner, 51 T.C.M. 432 (1986), where the Tax Court held that absent a binding commitment, and so long as there are valid non-tax business reasons for incorporating the business (i.e. other than to take advantage of the tax-free reorganization provisions), the step transaction doctrine would not apply.

${ }^{165}$ In the Bigco / small LLC merger scenario, it may be possible to use the 351 structure by giving the sellers shares of Newco but exchangeable into shares of the parent (Bigco). The validity of the structure would depend on whether such a strategy amount to a "plan" for purposes of the step-transaction doctrine. So if a startup were acquired by Cisco, the startups' owners would receive shares of Newco. The shares of Newco would be illiquid, but they would be exchangeable into shares of Cisco at the option of the shareholder.
} 
pay tax on the amount realized less basis, just as with any other asset. But the amount realized must be adjusted to account for the many aggregate-based rules of subchapter $\mathrm{K}$, such as increasing the amount realized to include the discharge of the partner's share of partnership liabilities. ${ }^{166}$ Complicating things further is $\S 751$ (a), which requires that selling partners recognize ordinary income on the sale of a partnership interest to the extent that the partnership has unrealized accounts receivable or inventory items. ${ }^{167}$

Alternatively, the partnership could sell its assets to the acquiror, with the partnership then distributing cash upstream to the various partners. Again, the liquidating distribution would trigger recapture provisions and other partnership tax rules. Unlike the sale of stock, which is usually a relatively simple affair with well-settled tax consequences, the sale of a partnership interest requires closer (and more costly) attention from the deal lawyers. ${ }^{168}$

But an asset sale from a partnership has the distinct advantage of giving the buyer a step up in basis in the target's assets without incurring an extra layer of tax. In order to get a step up in basis using the C Corp Structure, the startup must sell its assets to the buyer. The startup then recognizes income on the sale of the assets. Although the startup's NOL will help offset this tax liability, any additional appreciation will be taxed at the corporate rate of $35 \%$. To get the cash to the shareholders, the startup must then undergo a liquidating distribution, which is taxable to shareholders under $\S 331$. In contrast, if the Passthrough Structure is used, the asset sale will trigger one level of tax. Each partner recognizes its pro rata share of the partnership's income from the sale, but the liquidating distribution by a partnership is not taxable to the partners.

In sum, organizing a startup as a partnership or LLC is a great challenge for a smart lawyer but unappealing for clients who hope to minimize legal costs. With careful planning, the Passthrough Structure achieves many of the same goals regarding creating, running, and exiting a startup company, and it is advantageous if the preferred exit is a taxable asset sale to a trade buyer. But the Passthrough Structure is costly and complex,

\footnotetext{
${ }^{166}$ See $\S 741$.

${ }^{167}$ See $\S 751(a)$.

${ }^{168}$ See generally Philip F. Postlewaite, I Come to Bury Subchapter K, Not to Praise It, 54 Tax Lawyer 451
} (2001). 
and venture capital investors do not value the much-vaunted flexibility of the LLC form. It is not surprising, then, to see that entrepreneurs and VCs stick with the devil they know.

\section{Conclusion}

This Article has argued that the seemingly irrational decision to organize a startup as a corporation is, in fact, quite rational. The key factors are the limited ability of investors to use tax losses, agency costs, the tax treatment of gains, and the complexity of the Passthrough Structure. This Article has also demonstrated the value of avoiding the behavioral phenomena of optimism bias as a simple explanation for seemingly irrational behavior - at least in the context of sophisticated investors with a great deal of money at stake. Optimism plays a role, to be sure, but it is not the wild-eyed optimism of a naïve entrepreneur. Rather, the VCs' rational emphasis on the tax treatment of gains, not losses, and the various tax and nontax advantages of the corporate form make the corporation the preferred vehicle for financing a venture capital startup. And so tax plumbing ends up providing a workable, if inelegant, solution to this wonderful puzzle. 